\title{
EKSOTIKA TENUN PAGATAN
}

Eksotika Tenun Pagatan

Hak Cipta Dilindungi Undang-Undang

Dilarang memperbanyak atau memindahkan sebagian atau seluruh isi buku ini dalam bentuk apapun secara elektronik maupun mekanik termasuk memfotocopy, merekam atau dengan teknik merekam lainnya tanpa izin tertulis dari penerbit.

Disusun dan diterbitkan oleh

Banjarmasin Post

Penulis

Sri Hidayah

\section{THE EXOTICA OF TENUN PAGATAN}

THE EXOTICA OF TENUN PAGATAN

All rights reserved

No part of this publication may be reproduced, stored in a retrieval system or transmitted, in any form or by any means, electronic, mechanical, photocopying, recording or otherwise, without the prior permission of the publishers

Printed and bound by

Banjarmasin Post

Author

Sri Hidayah 


\section{Daftar Isi}

Daftar isi

Kata Pengantar

Pagatan yang Menyimpan Warisan Budaya

DetakTenun

Dari Gedok ke ATBM

Ragam Tenun Pagatan

Rangkaian Sebuah Penciptaan

Inspirasi dari Alam

Tenun Pagatan dalam Produk

Generasi Penerus

\section{CONTENTS}

Table of Content

Introduction

Pagatan that Keeps Cultural Heritage

The Ticking Loom

From Gedok to ATBM

Manners of Tenun Pagatan

Sequence of a Masterpiece

Inspiration from Nature

Tenun Pagatan in Products

Next Generation

\section{Kata Pengantar}

Kalimantan Selatan menyimpan ragam warisan budaya masyarakatnya. Adalah Kecamatan Kusan Hilir Kabupaten Tanah Bumbu dapat dijumpai sedikitrnya 25 orang penenun. Mereka mengenalkan Tenun tradisional ini ke pelbagai daerah dan sering dijadikan studi dan inspirasi. Penduduk di daerah in
Pagatan telah diwariskan dari generasi ke generasi yang menghasilkan sebuah produk yang berisi estetika dan nilai-iliai kearifan lokal.

Keberadaan Tenun Pagatan sejak dua abad yang Ilalu ada dalam pusaran sejarah dan bagian dari Tenun di Nusantara. Kecanggihan persaingan pasar tekstil sekarang 作 berkreasi dengan sentuhan wanna dan molf tanpa kehilangan jatidinhya. Buku ini sebagai untaian rasa kekaguman akan jiwa kewirausahaan penenun Pagatan yang sanga

Ucapan terima kasih kepada semua pihak atas terbitnya buku ini terutama Bapak H.Gusti Pangeran Rusdi Effendi, Bapak Yusran Pare dari Banjarmasin Post, Bupati

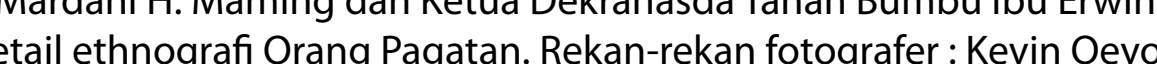

\section{Introduction}

South Kalimantan keeps many kinds of its society's cultural heritage. It's the sub-district of Kusan Hilit, Tanah Bumbu Regency found approximately 25 weavers. They introduce this traditional weave to various places which often becomes a study and inses
generation to generation resulted a product filled with esthetic and local values.

The presence of Tenun Pagatan has been in historical rotation and part of Tenun in Indonesia archipelago since over than two centuries. A sophisticated textile market motives without losing its true identity - This book is as an admiration to enormous spiriti of Pagatan weavers' entrepreneurhip and a hope to arise others' concern. A gratitude to all people toward this published book especially Bapak H. Gusti Pangeran Rusdi Effendi, Bapak Yusran Pare from Banjarmasin Post, Regent of Tanah Bumbu, 作 every detail of Pagatan's native ethnographic. My photographer colleagues: Kevin Oeyono, Nadi and Zadhe
siah and all of associates that have involved in this project and publishing this book, thank you everyone. 


\section{PAGATAN}

YANG MENYIMPAN WARISAN BUDAYA

Pagatan merupakan salah satu kecamatan di Kabupaten Tanah Bumbu. Wilayah Kecamatan sebagian besar dataran rendah yang berawa-rawa. Pagatan berada daerah pantai yang tumbuh bakau, nipah, dan kelapa. Beberapa tumbuhan khas Kalimantan dapat dijumpai di daerah ini seperti ramania, durian dan kasturi.

\section{PAGATA N \\ that Keeps Cultural Heritage}

Pagatan is one of sub-districts in Tanah Bumbu Regency. This area is mainly low plain that swampy. Pagatan is located on coastal area that grown mangroves, nipa palm, and coconuts. Slightly in some spots also grown a typical Kalimantan fruit like ramania, durian and kasturi. 


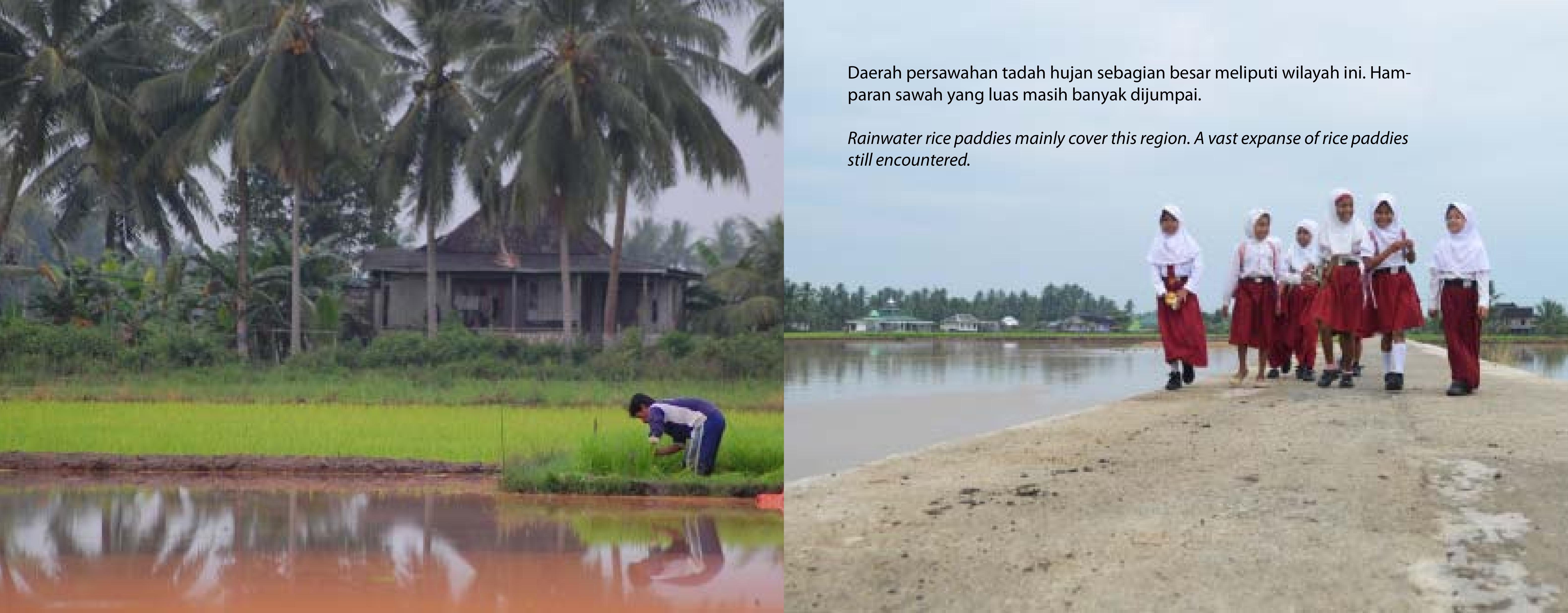




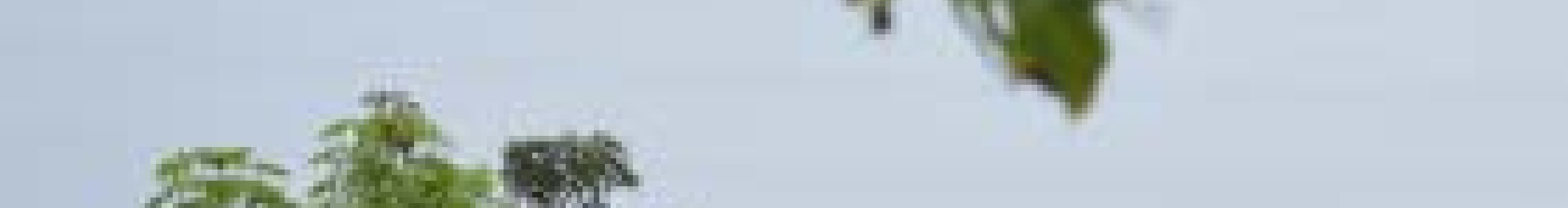

\section{4}

48.

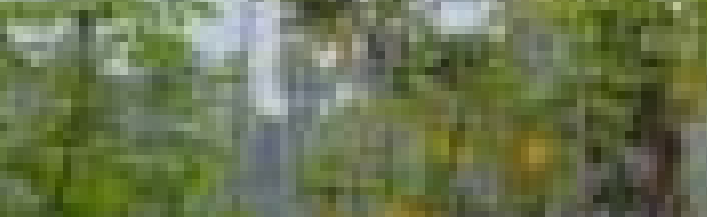

.

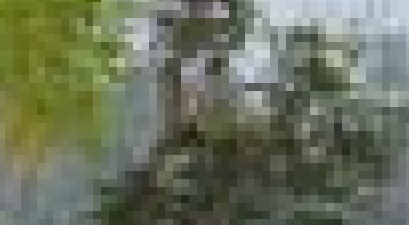

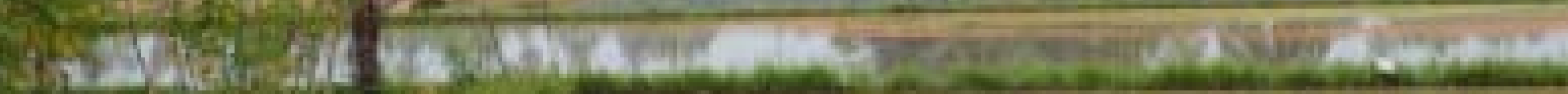
Cxes

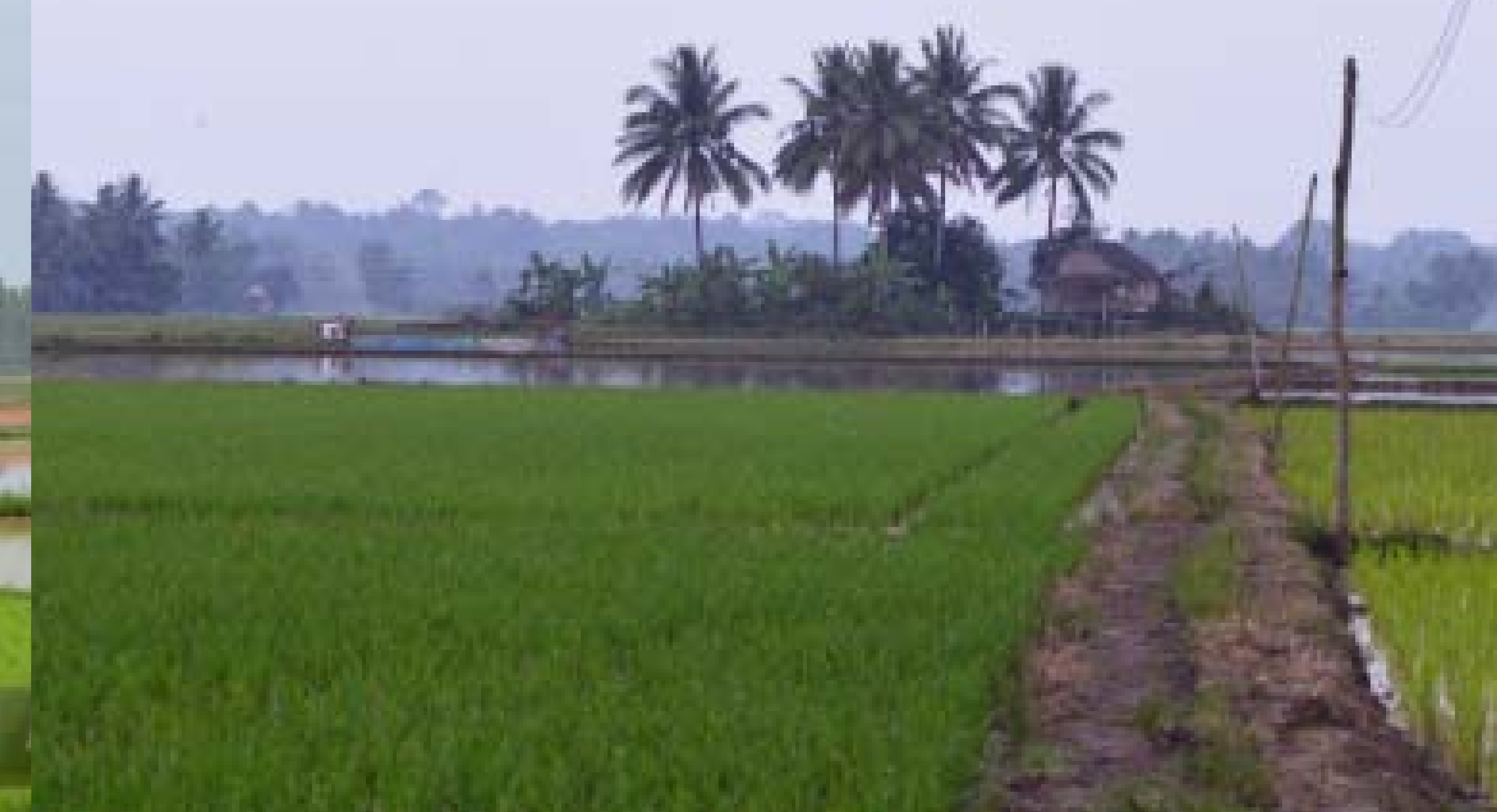

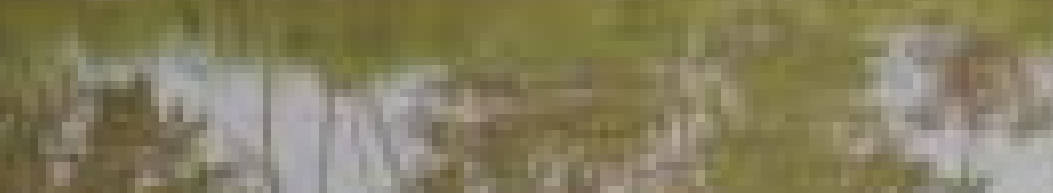

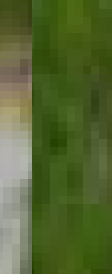


Rumah tradisonal orang Pagatan nampak dibangun diarea persawahan sebagai bukti bahwa mereka hidup menyatu dengan alam

A traditional house of Pagatan people built appears along rice field as a proof that they live with nature
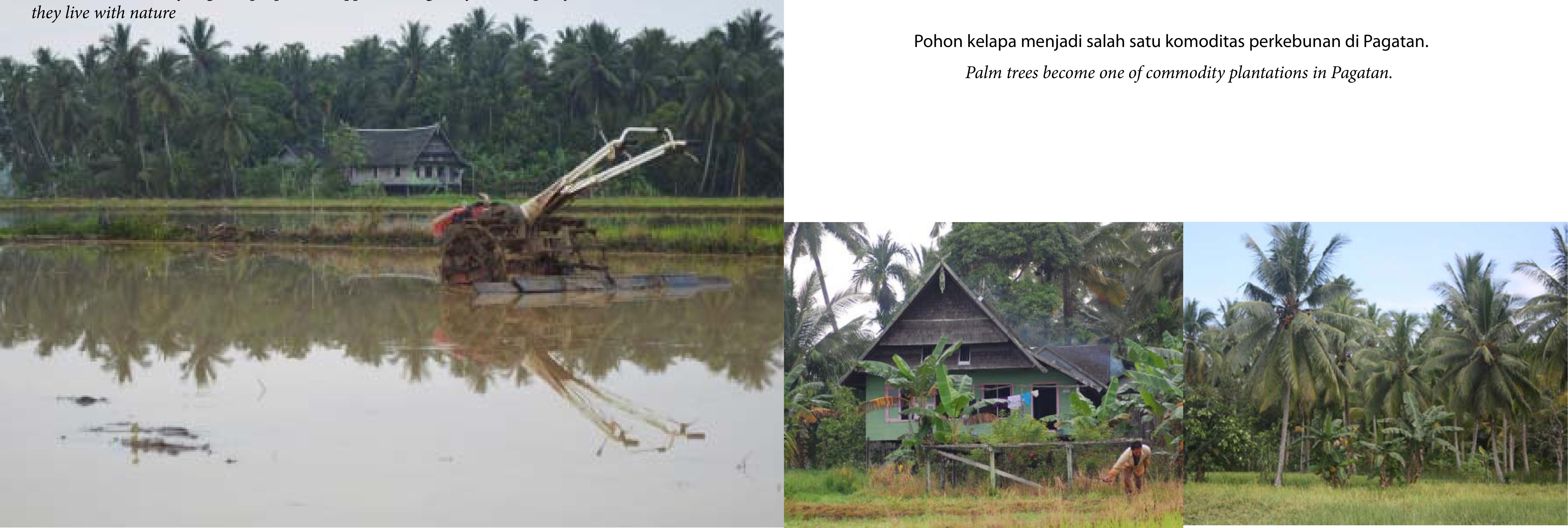

Pohon kelapa menjadi salah satu komoditas perkebunan di Pagatan.

Palm trees become one of commodity plantations in Pagatan. 
Sungai Kusan membelah kota Pagatan sebagai salah satu urat nadi perekonomian masyarakat.

Kusan River divides the city of Pagatan as one of community economy veins

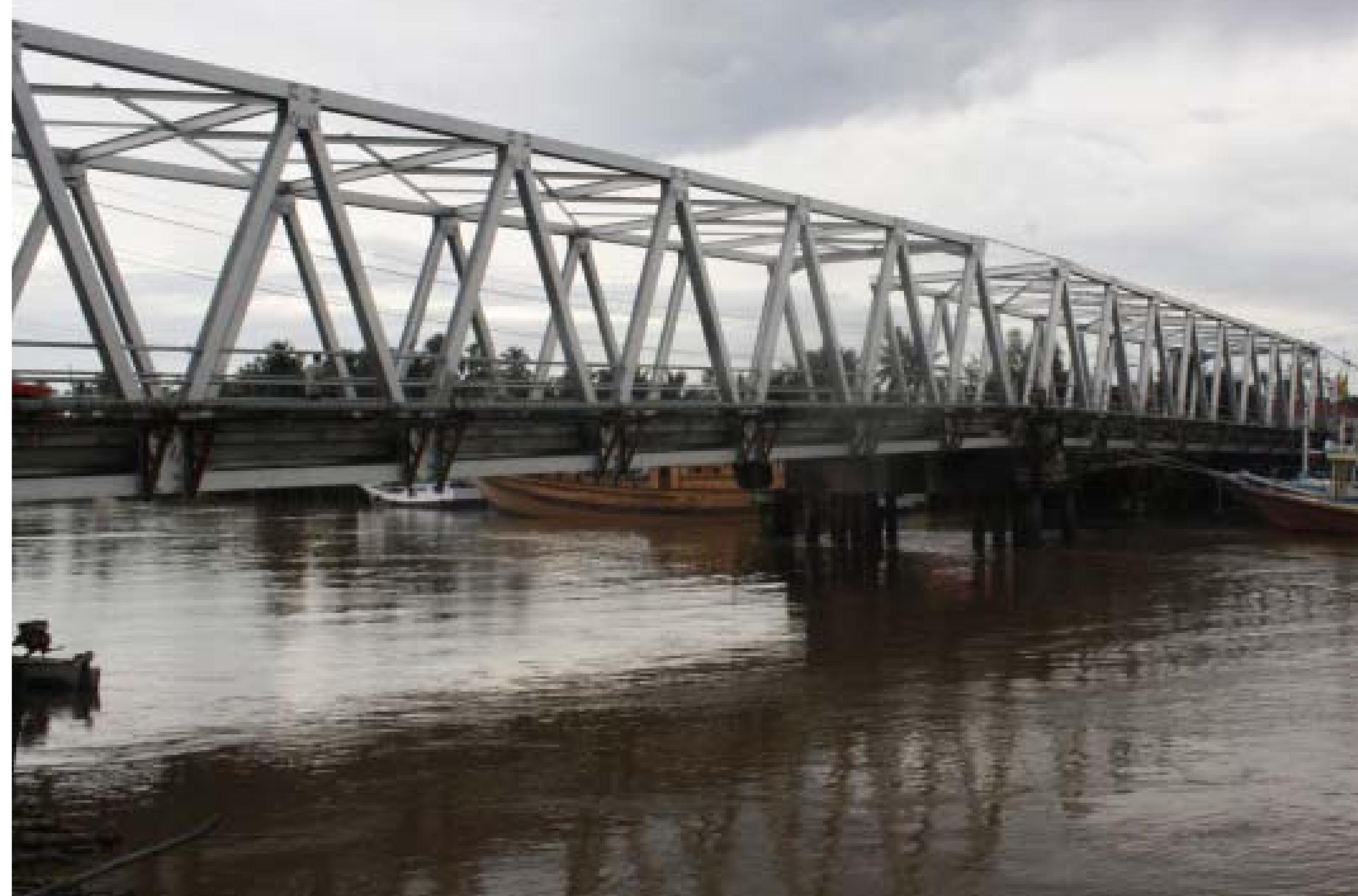




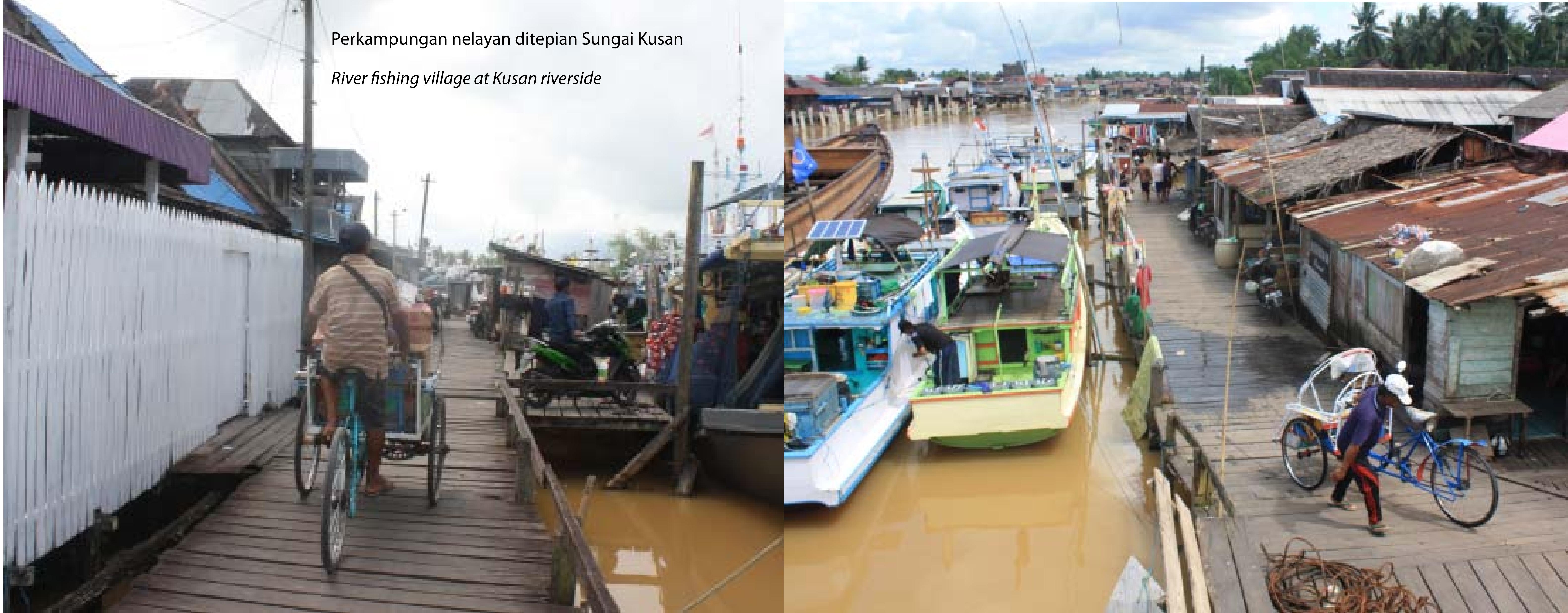




\section{Perkampungan di pinggir sungai Kusan}



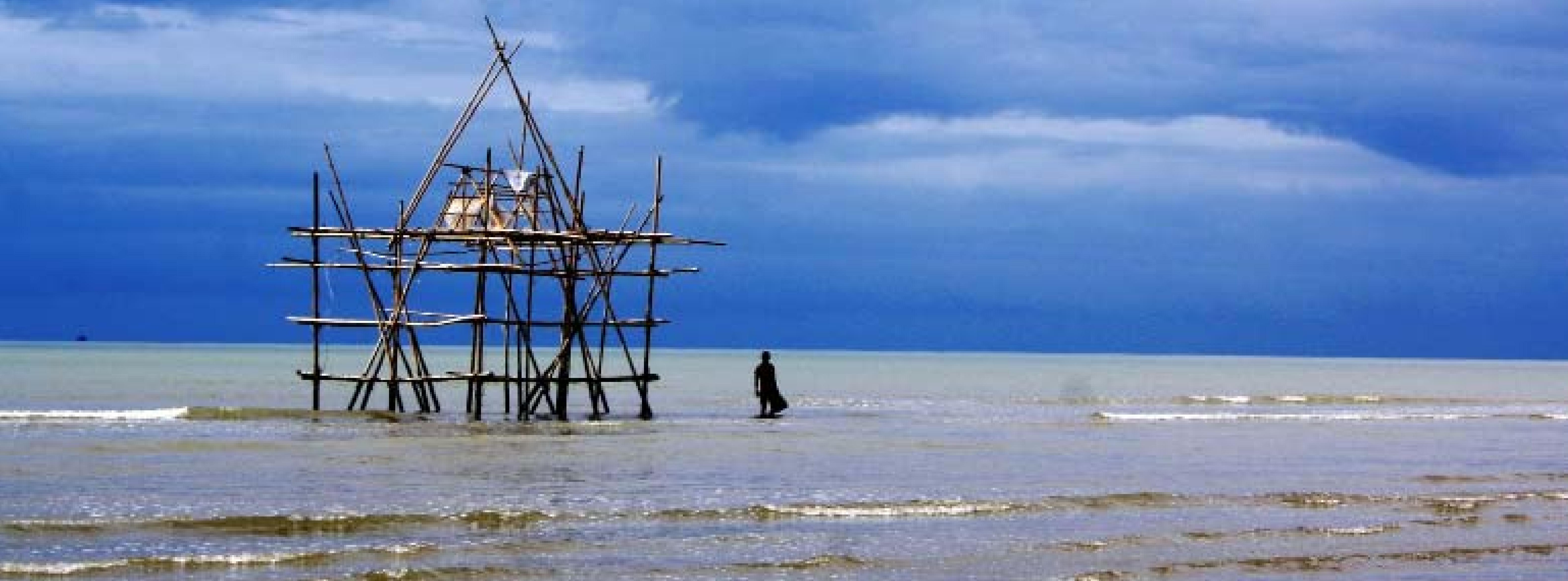


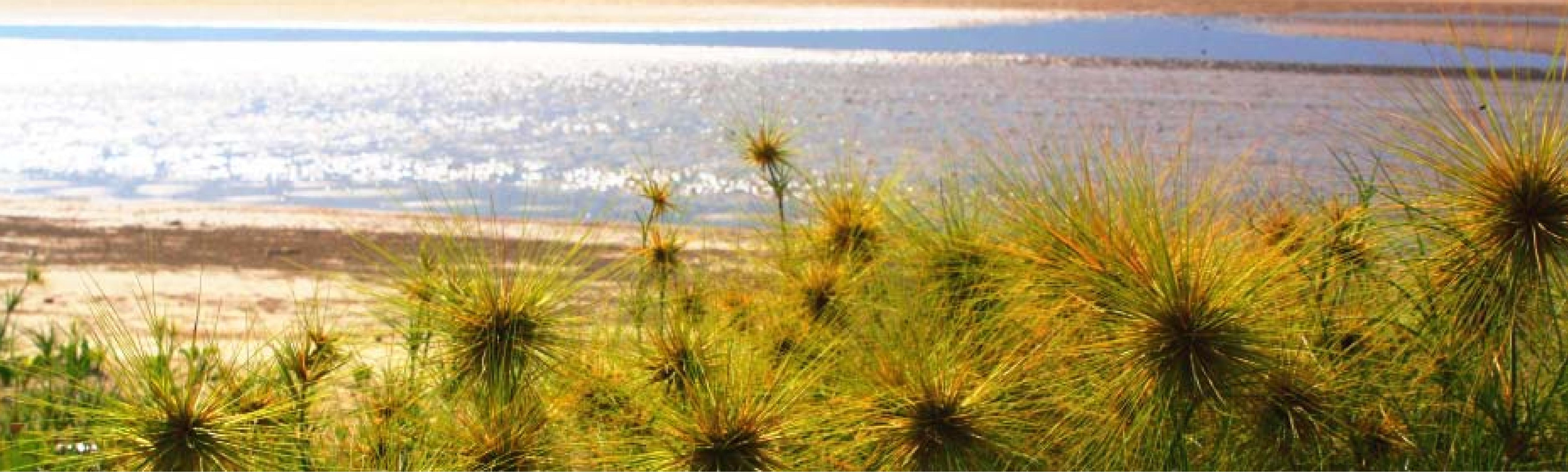


Sejarah Pagatan tidak terlepas dari keberadaan suku Bugis yang telah bermukim di Kalimantan sejak pertengahan abad 18 dan berkembang hingga abad ke-19 dan abad ke-20. Migrasi suku Bugis ke Kalimantan dilatarbelakangi oleh semangat merantau atau berlayar untuk mencari kehidupan yang lebih baik.

History of Pagatan is inseparable from the existence of Buginese ethnic who had settled in Borneo since the mid 18th century and grew until 19th and 20th century. The migration of the Buginese to Borneo effected by the spirit of wandering or sailing to search a better life. B. better life.

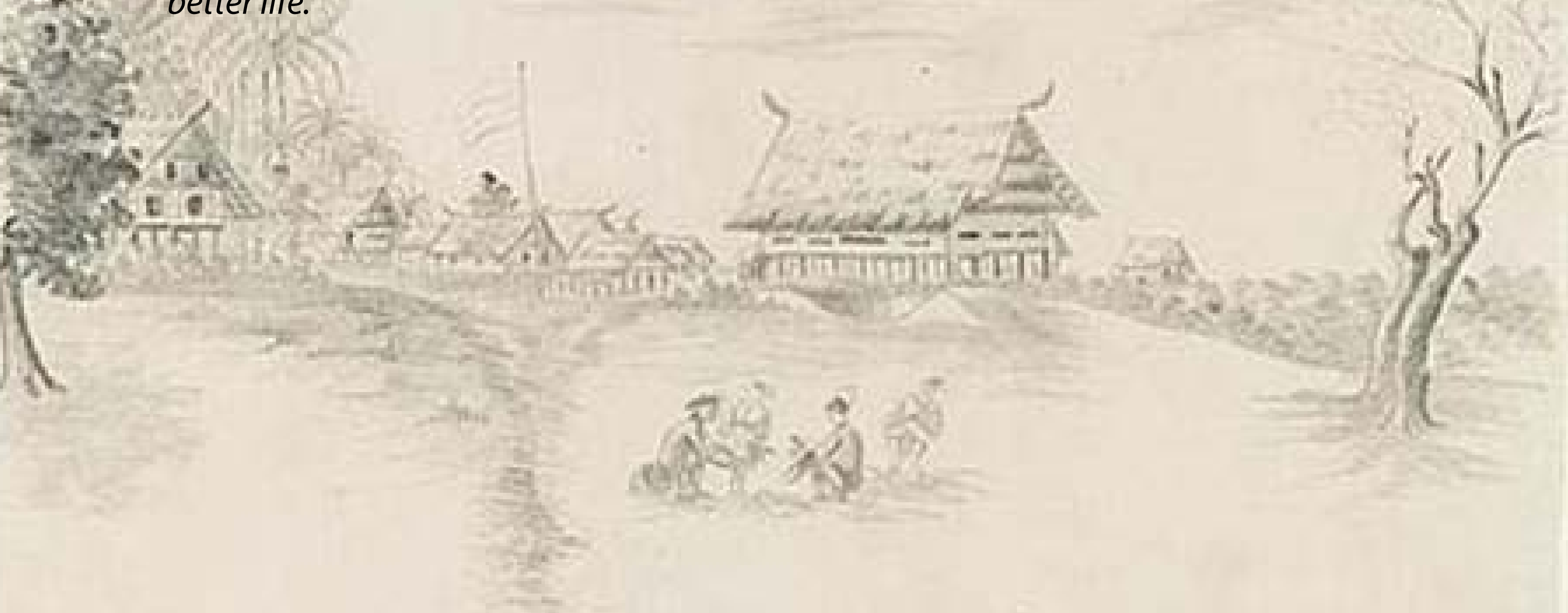

Lukisan Heinrich von Gaffron berjudul Istana Kerajaan"Pagatan Tahun 1845 A Portrait of Heinrich von Gaffron titled Pagatan's Royal Palace in 1845

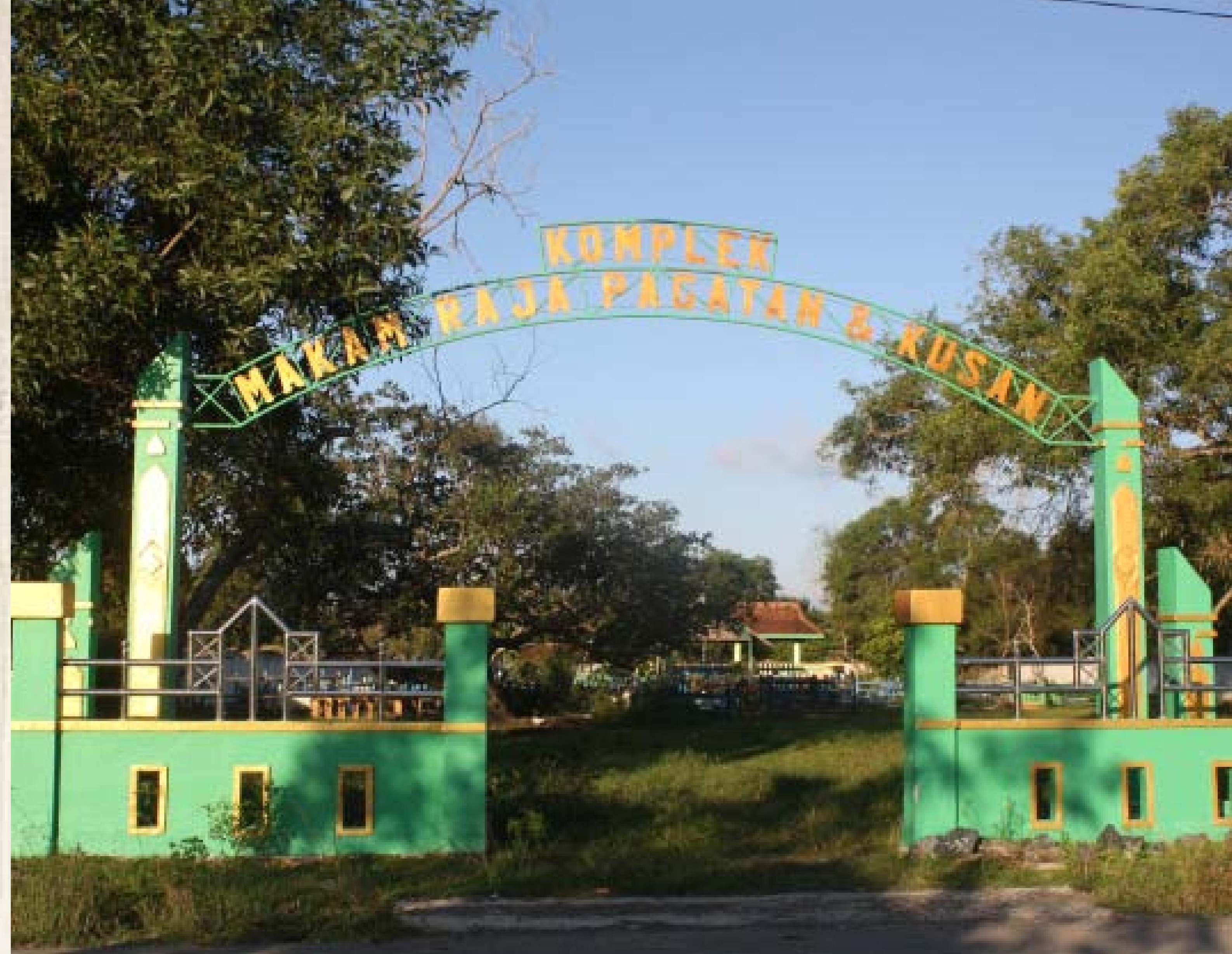




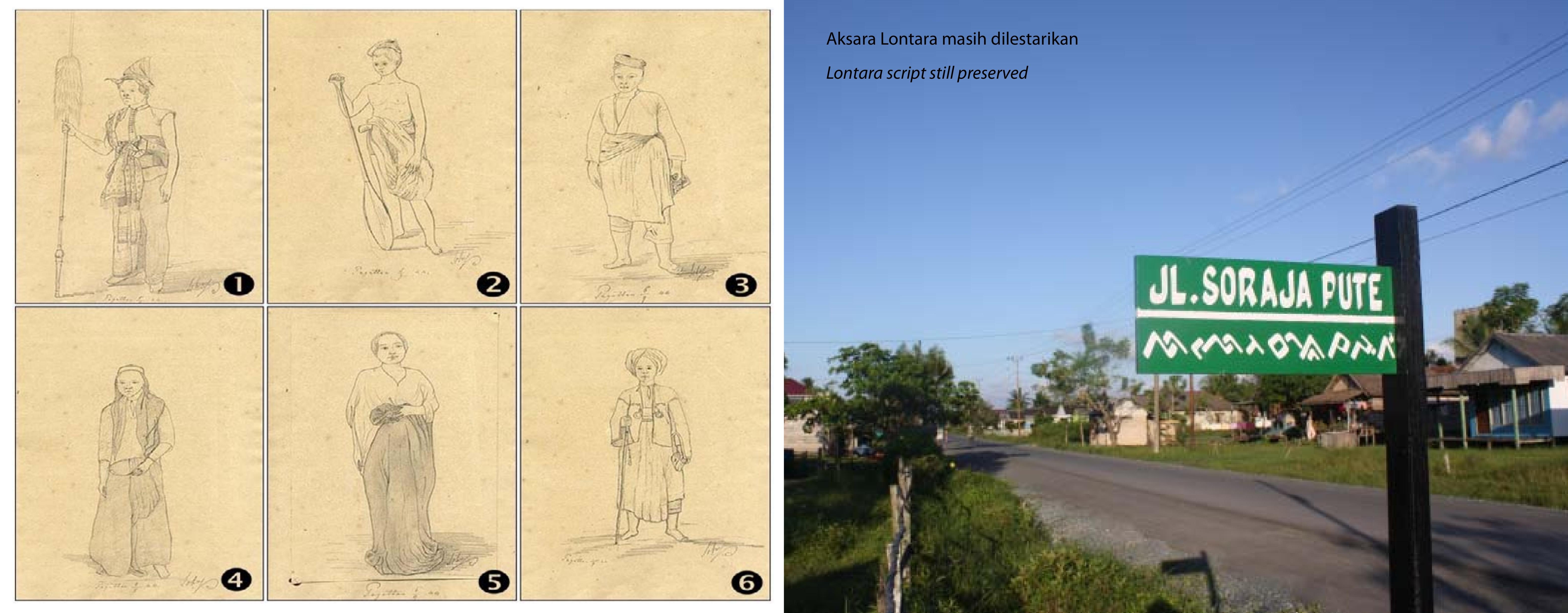


Picture (Lukisan) :

1) “Gevechtskleding van een welgestelde Boeginees" (Pakaian tempur orang kaya Bugis).

2) "Kleding van slaven en arme Boeginezen (Pakaian budak/orang miskin/ nelayan kelas bawah).

3) "Kleding van een welgestelde Boeginees" (Pakaian laki-laki Bugis dari kalangan kaya ).

4) "Een Tjilabay in vrouwenkleding" (Pakaian Tjelabay/calabai atau

Banci).

5) "Een vrouw uit een welgestelde bevolkingsgroep" (Pakaian wanita Bugis kalangan kaya).

6) "Kleding van een welgestelde Boeginees" (Pakaian Imam Bugis).

7) "Jonge Boeginese vrouw met meisje" (Pakaian gadis remaja dan anak wanita).

8) "Oude Boeginese Vrouw" (Pakaian wanita Bugis model lama).

9) “Een vrouw uit een lagere bevolkingsgroep" (Pakaian penduduk

wanita miskin/kelas bawah).

\section{Nama-nama jalan dengan bahasa etnik Bugis} The names of the roads with Buginese ethnic language 


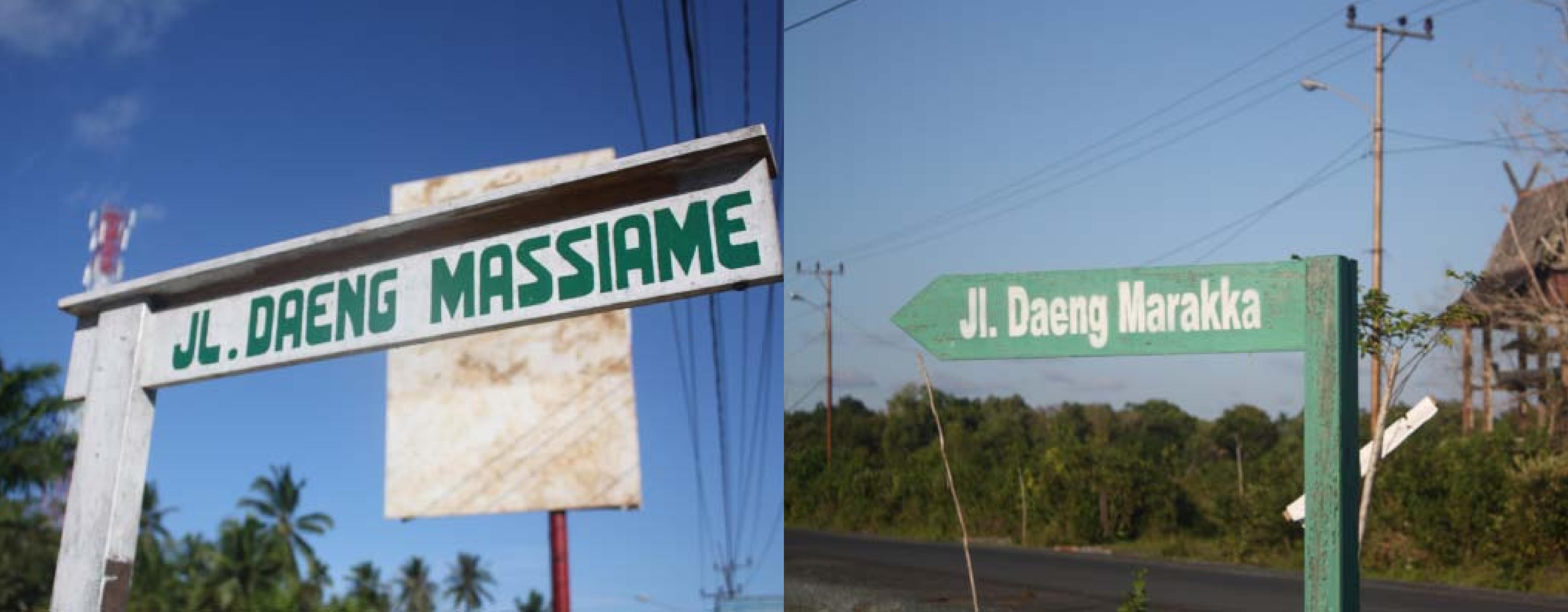




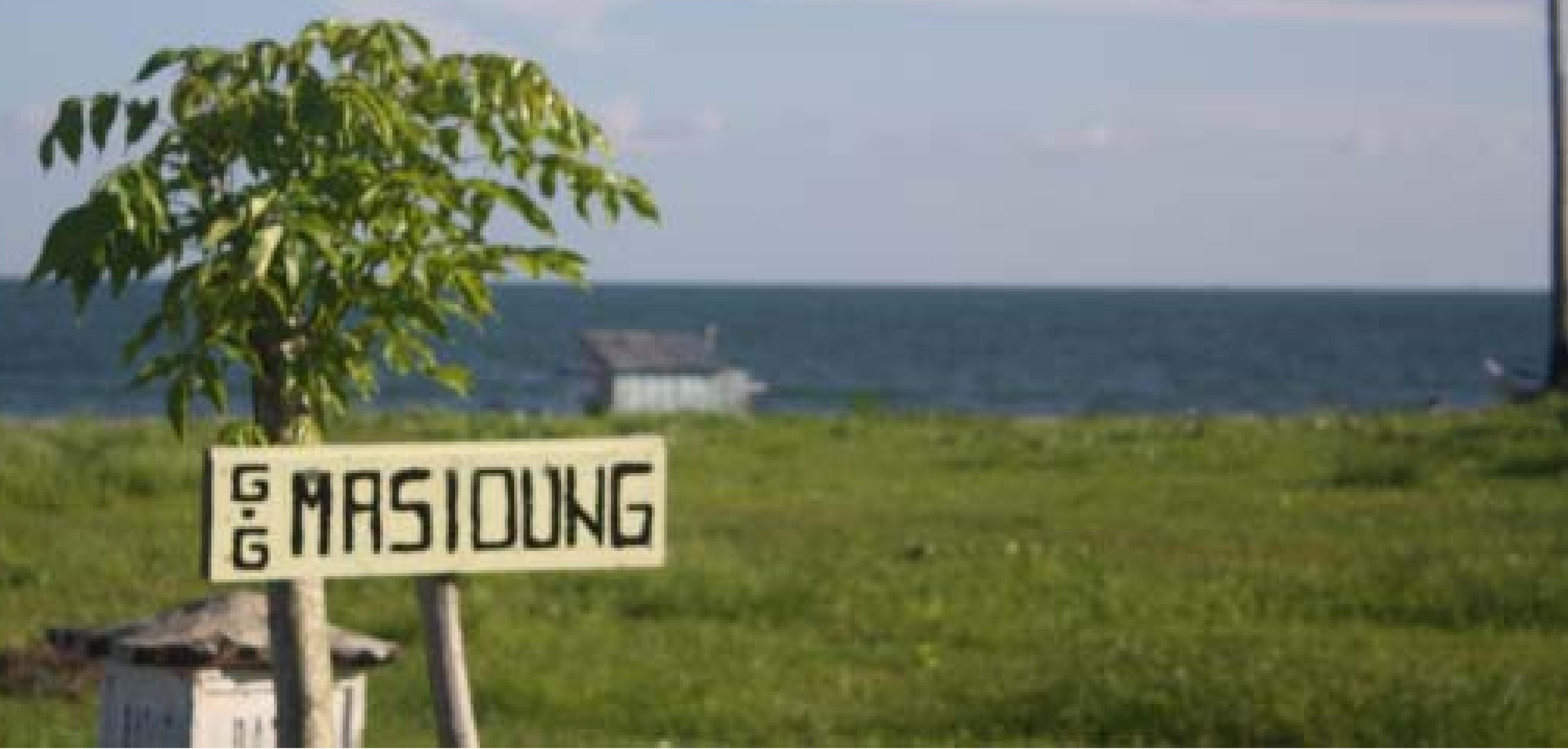




\section{the}

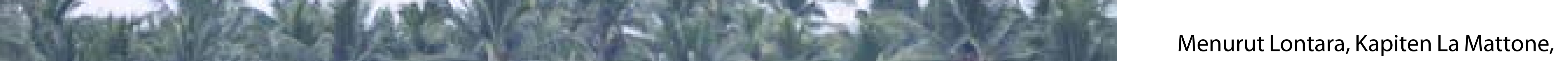

1.

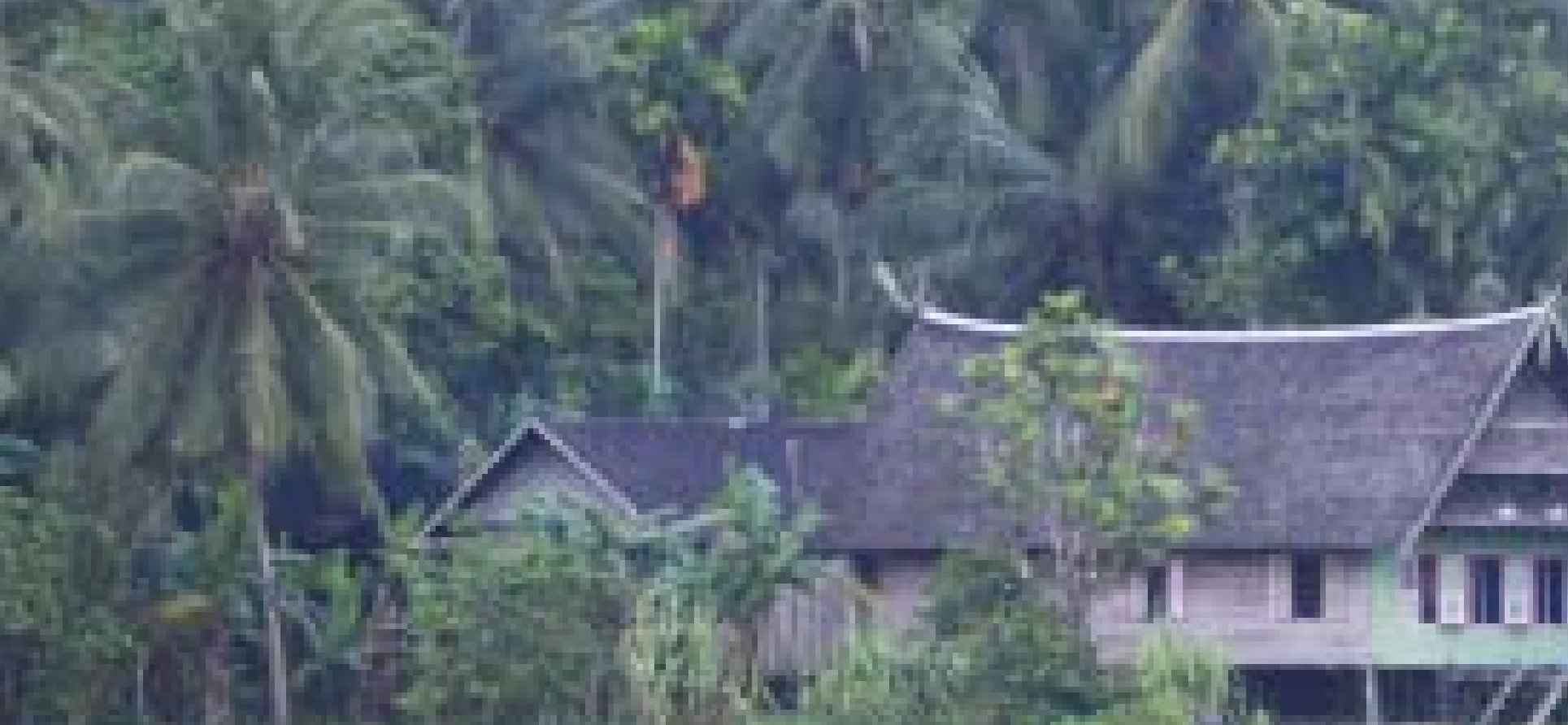

Rumah tradisional etnik Bugis masih banyak terdapat di Pagatan yang dikelilingi kebun kelapa dengan penggalian parit yang teratur untuk tiap jalur menuju kebun.

Traditional house of Büginese ethnic still found in Pagatan surrounded by coconut groves with a regular trench excavation for each line to the garden.
Pena Dekke adalah Kakek dari Raja dagar Pena Dekke membawa serta penetus 1868 yang menceritakan bahwa asal nun Bugis dari Tanah Wajo.

mula Pagatan dibuka oleh Saudagar dari

Para penenun dari Tanah Wajo itulah Tanah Bugis Wajo yang bernama Pena yang menurunkan keahlian menenun di Dekke.

Tanah Pagatan

\section{THE TICKING LOOM}

According to the Lontara, Captain La

Pena Dekke is the grandfather of first Mattone, a Minister of Pagatan and Ku-Pagatan King. It is likely that the merchants san Kingdom written on the 2nd Jumada Pena Dekke brought the Bugenese weavAl-Awwal 1285 Hijri 21 August 1868 which ers from Wajo land.

tells the origin of Pagatan opened by the The weavers from the Wajo Land that merchant from Land of Bugenese Wajo handed over the expertise of weaving in named Pena Dekke. Pagatan. 


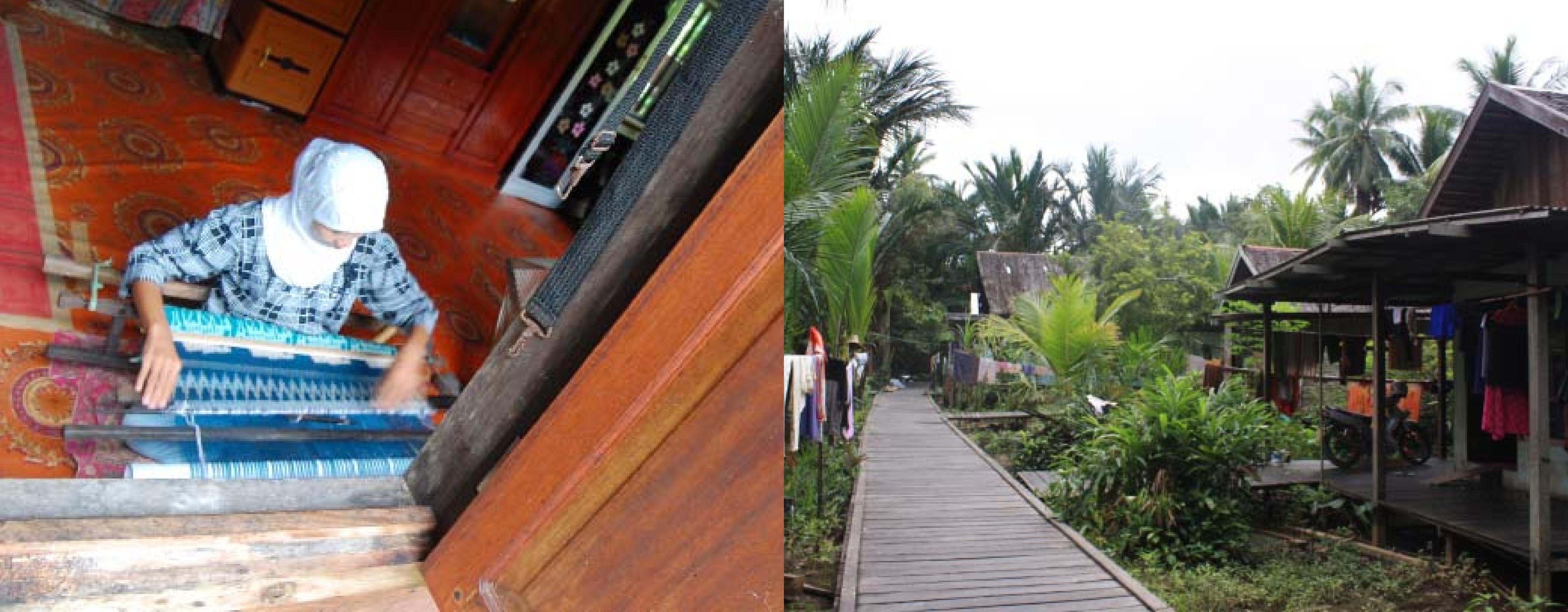




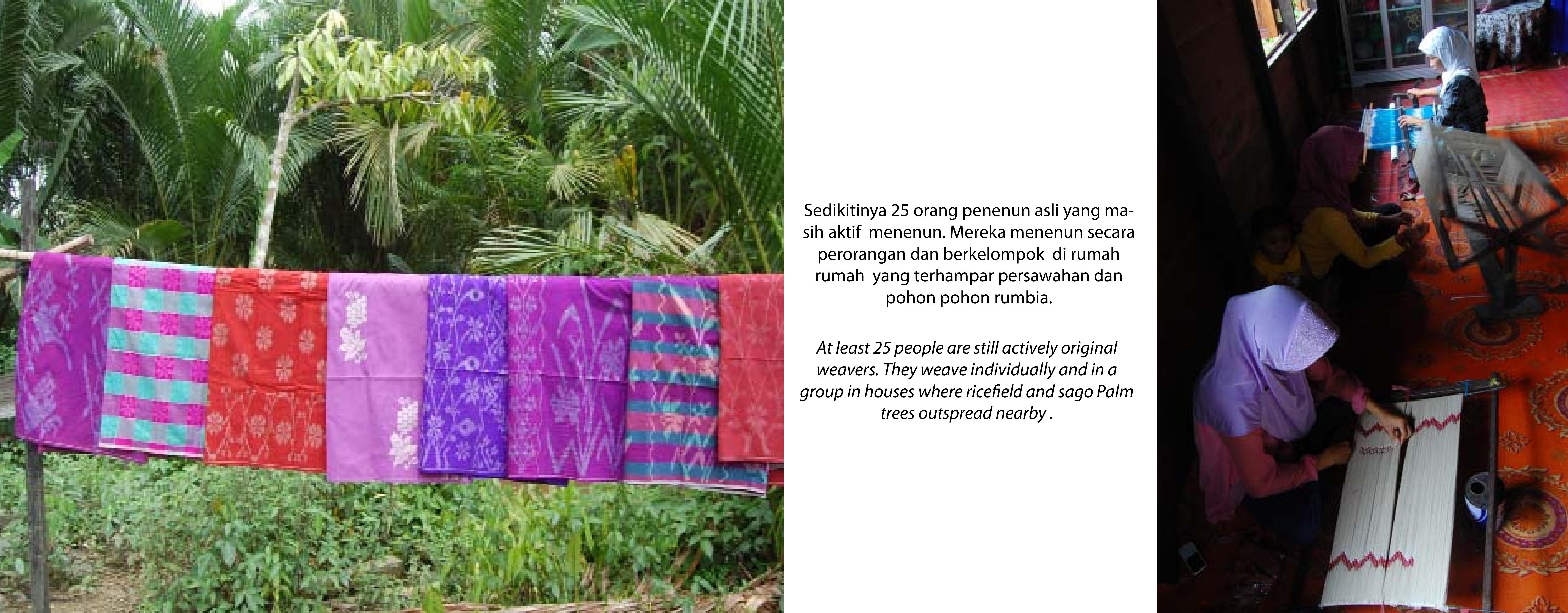



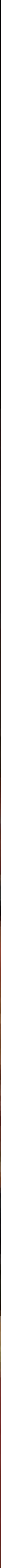
Dan ketika alat mulai berdetak, seperti suara musik tradisional yang berirama, memadukan kesan elegan dengan keindahan tiada tara. Iringan alat tenun Gedok memberi semangat untuk terus menenun benang demi benang

And when the tool begins to beat, like the rhythmic sound of traditional music, elegant blends with incomparable beauty. Accompaniment of Gedok gives spirit to continue to weave thread by thread. 


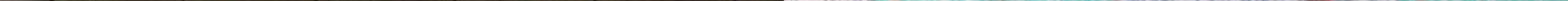




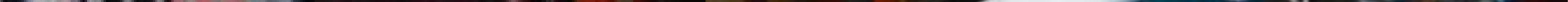

Pagatan bukan hanya sebuah kampung nelayan dengan laut dan hasil ikan yang melimpah, tapi juga tempat berpenghidupan bagi perempuan menenun menghasilkan kain-kain yang indah.

Pagatan not just a fishing village with sea and abundant fish, but also a place for livelihood for women weave producing beautiful fabrics 
Alat Tenun Bukan Mesin (ATBM) digerakkan dengan injakan kaki untuk mengatur irama benang. Dengan menggunakan alat ini, dalam satu hari bisa dihasilkan $3-5$ meter kain dengan lebar 70, 90, dan $110 \mathrm{~cm}$.

\section{FROM GEDOK TO ATBM (Alat Tenun Bukan Mesin) Non-machine Loom}

ATBM powered by putting feet to set thread rhythm. By using this device, in a day can deliver 3-5 meters cloth, width 70,90, and $110 \mathrm{~cm}$. 


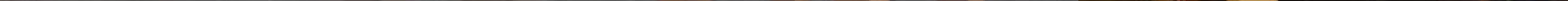


Walaupun menenun menggunakan Alat Tenun Bukan Mesin (ATBM), Gedok tetap dipertahankan.

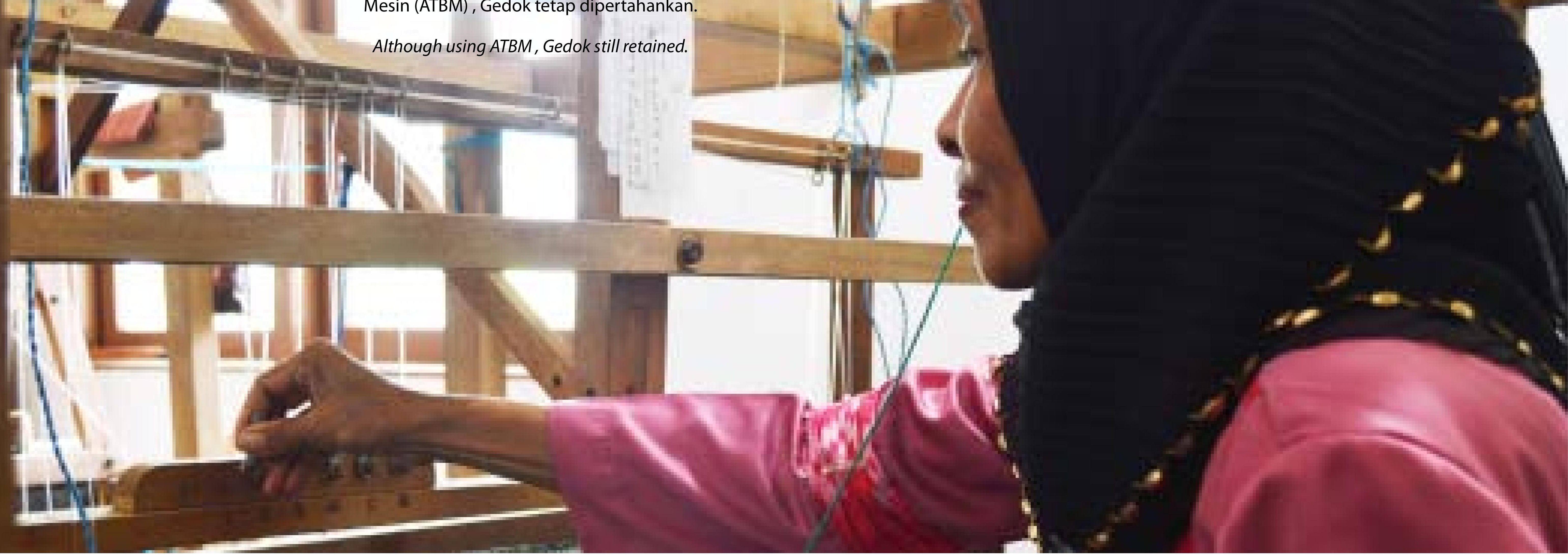




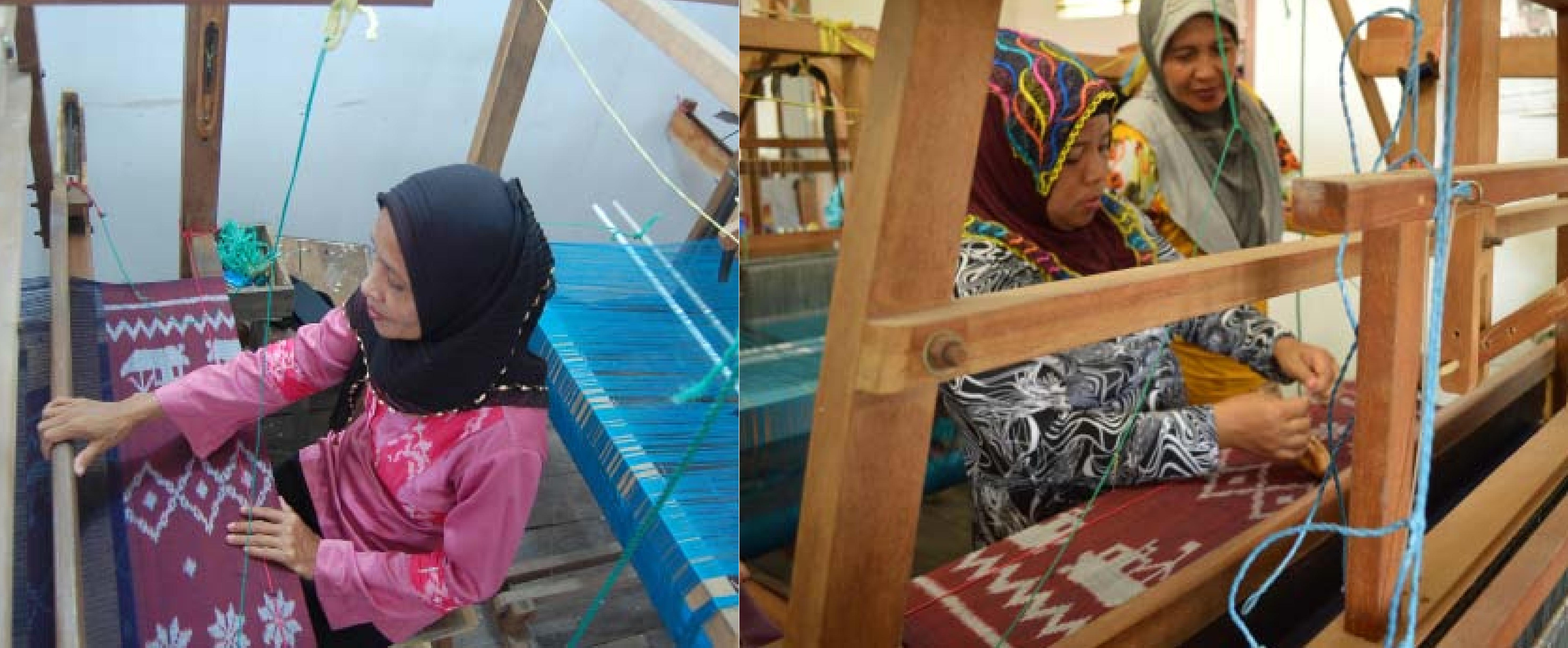




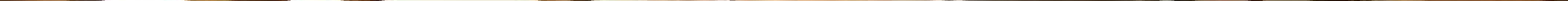




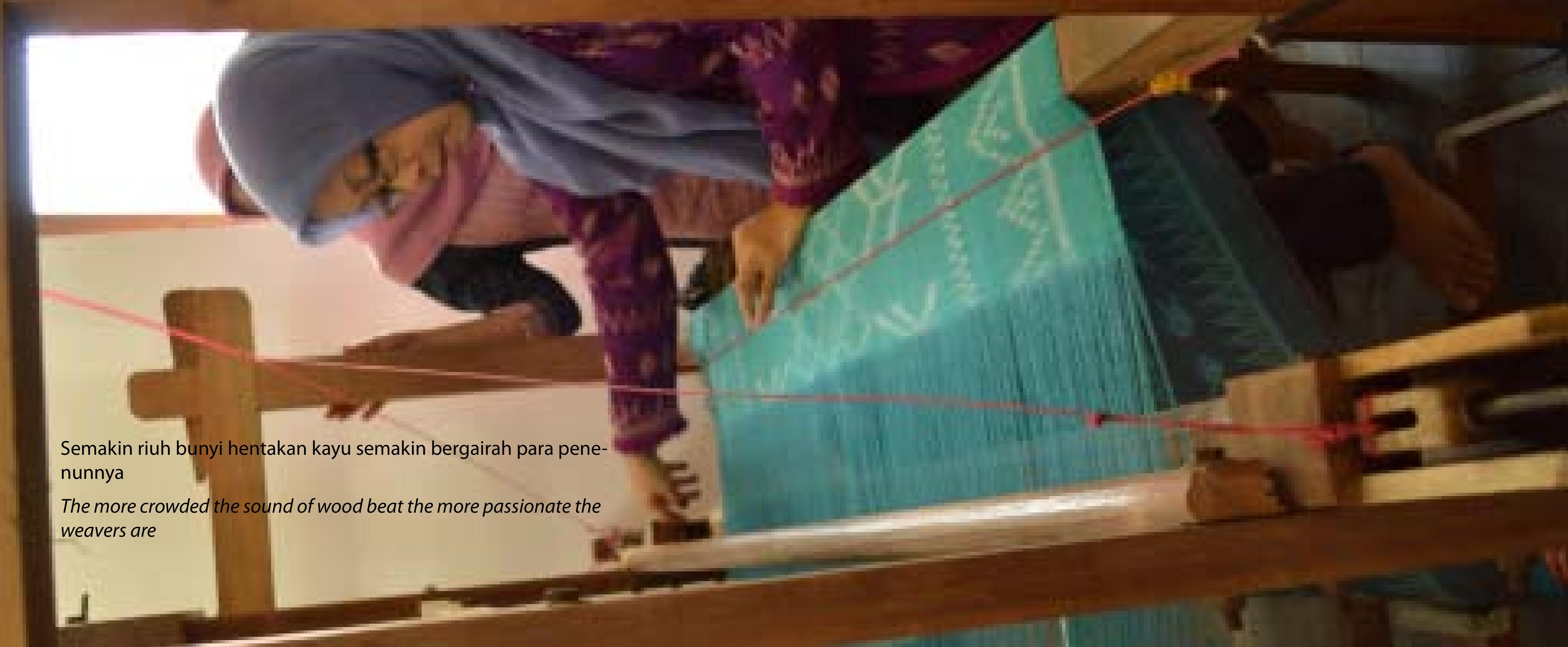




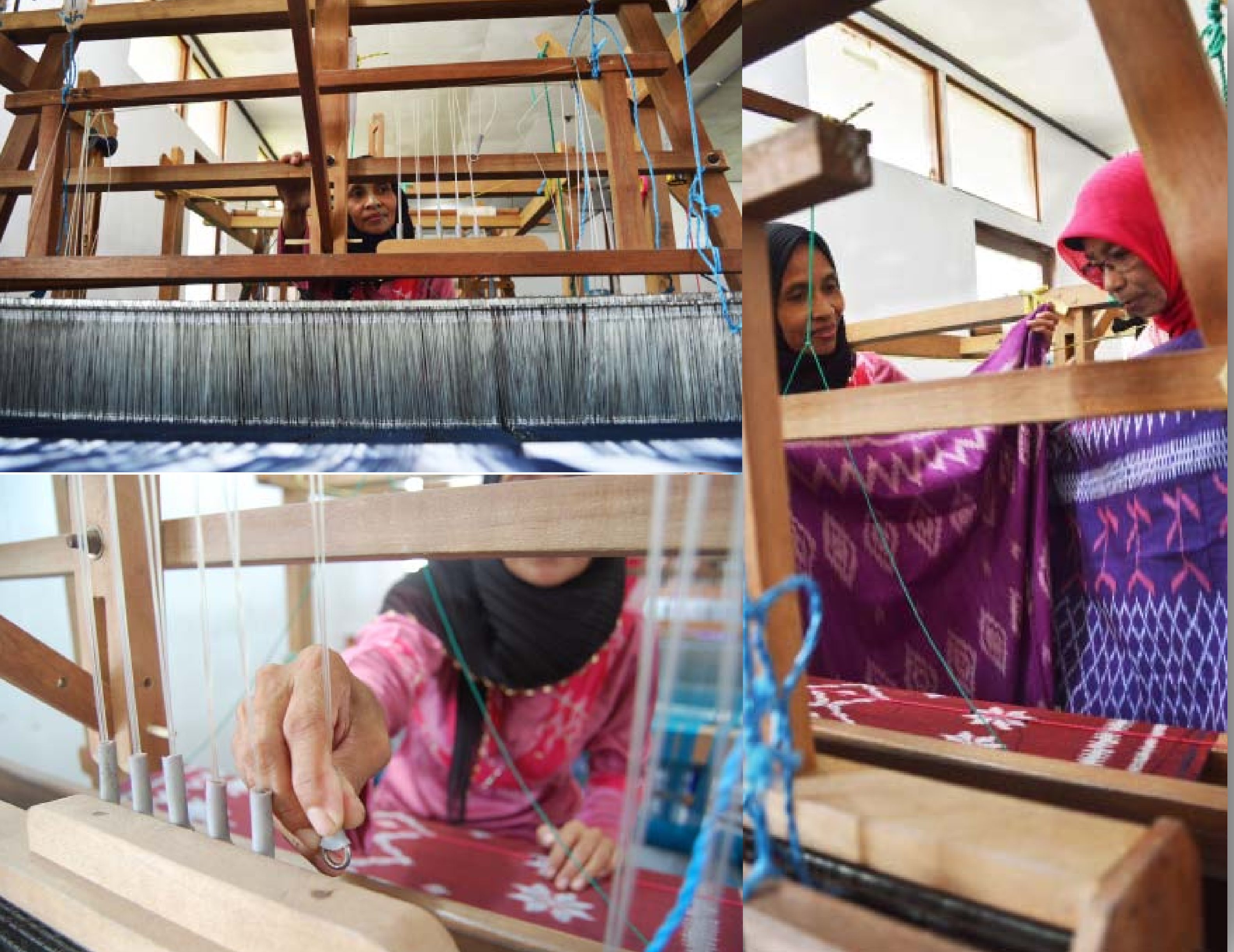

Dengan ATBM penenun bekerja dalam waktu yang lebih pendek. 


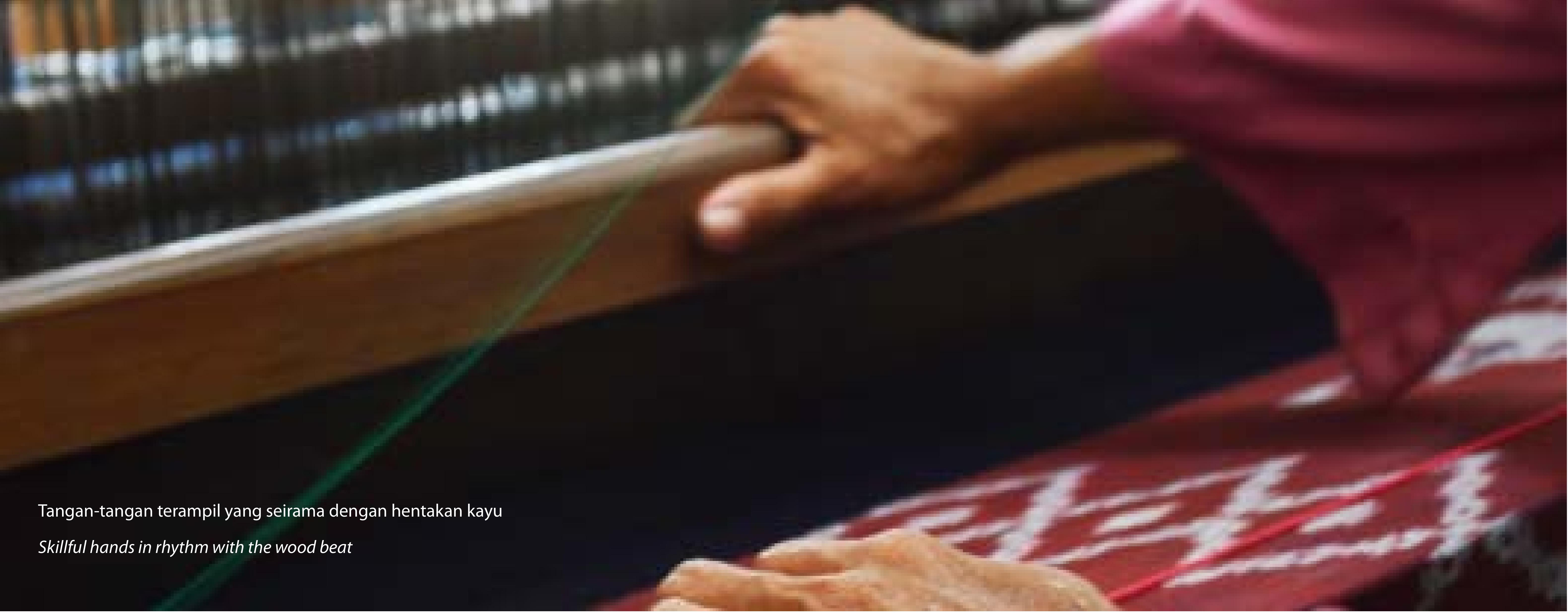




\section{Ragam Tenun Pagatan}

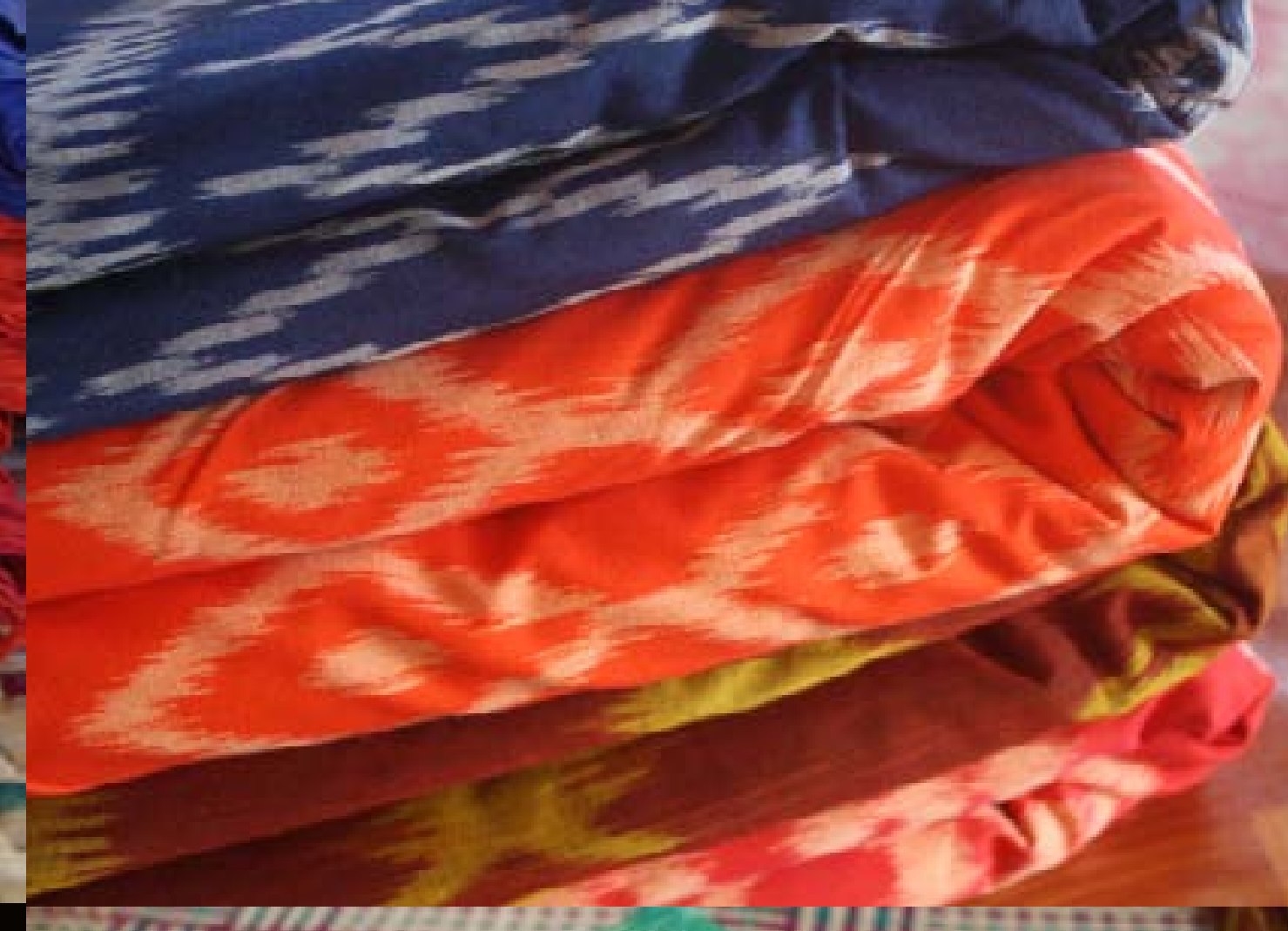

Ragam Tenun Pagatan menunjukkan sebuah identitas budaya dan tradisi yang masih dipertahankan hingga kini. Ragam ragam ini menjadi dasar proses pembuatan Tenun Pagatan.

So'be Are dibuat dengan cara menyisipkan benang Tenun untuk membuat motif tertentu dengan menembus ke bagian dalam.

\section{Manners of Tenun Pagatan}

Manners of Tenun Pagatan show an identity of culture and tradition which retained up until now. These varieties are the bases of making the textile.

So'be Are created by way of inserting the yarn to make a particular motive with penetrating to the inside.

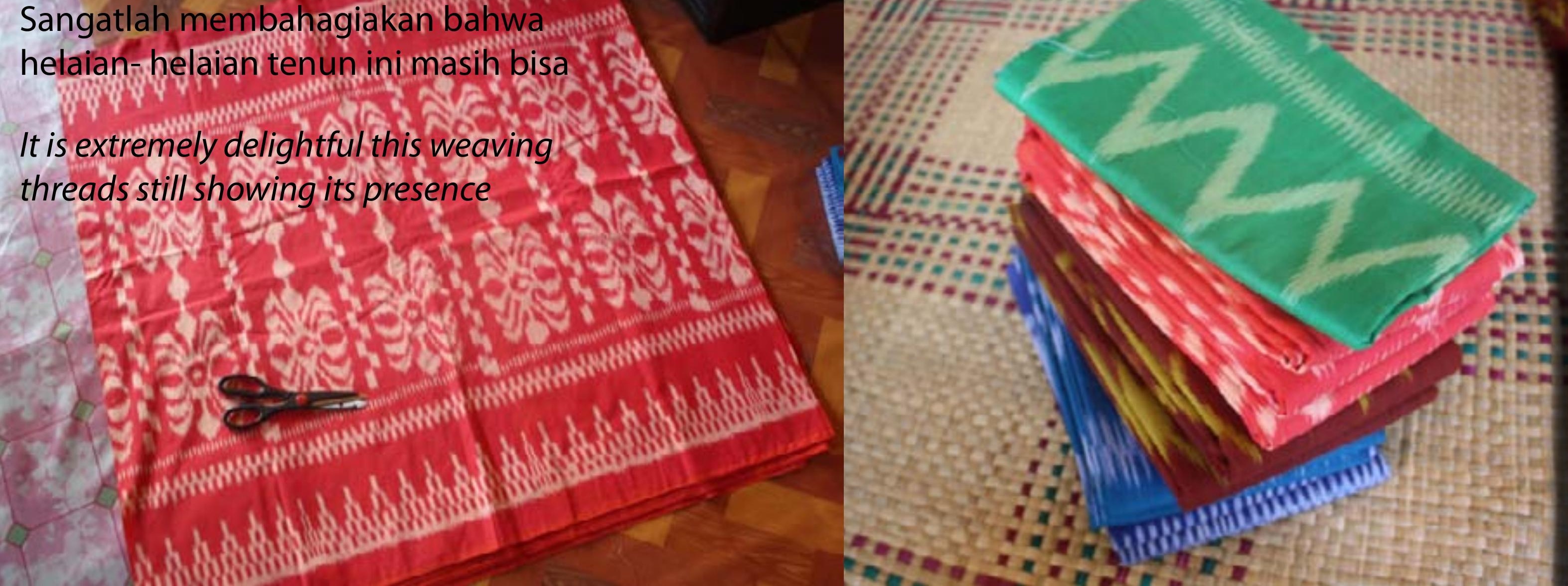
hetaian-heląian tenun inimasili bisa (1) threads stillshor

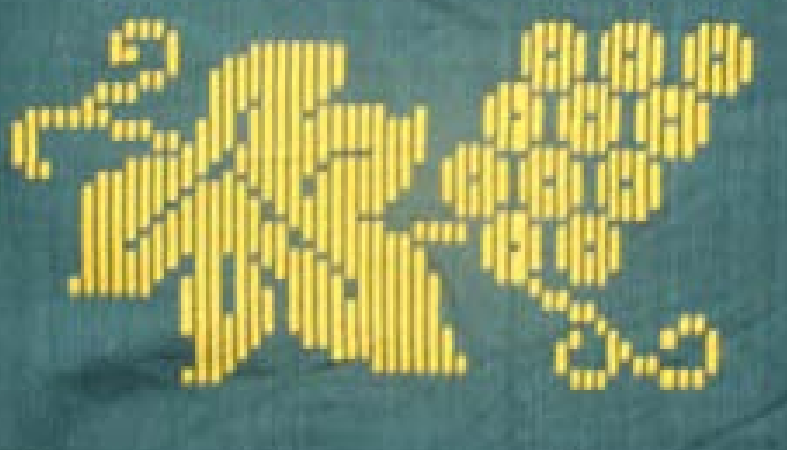




\section{Songket So'be sumelang motif Anggur}

\section{Songke So'be Sumelang, Grape motive}

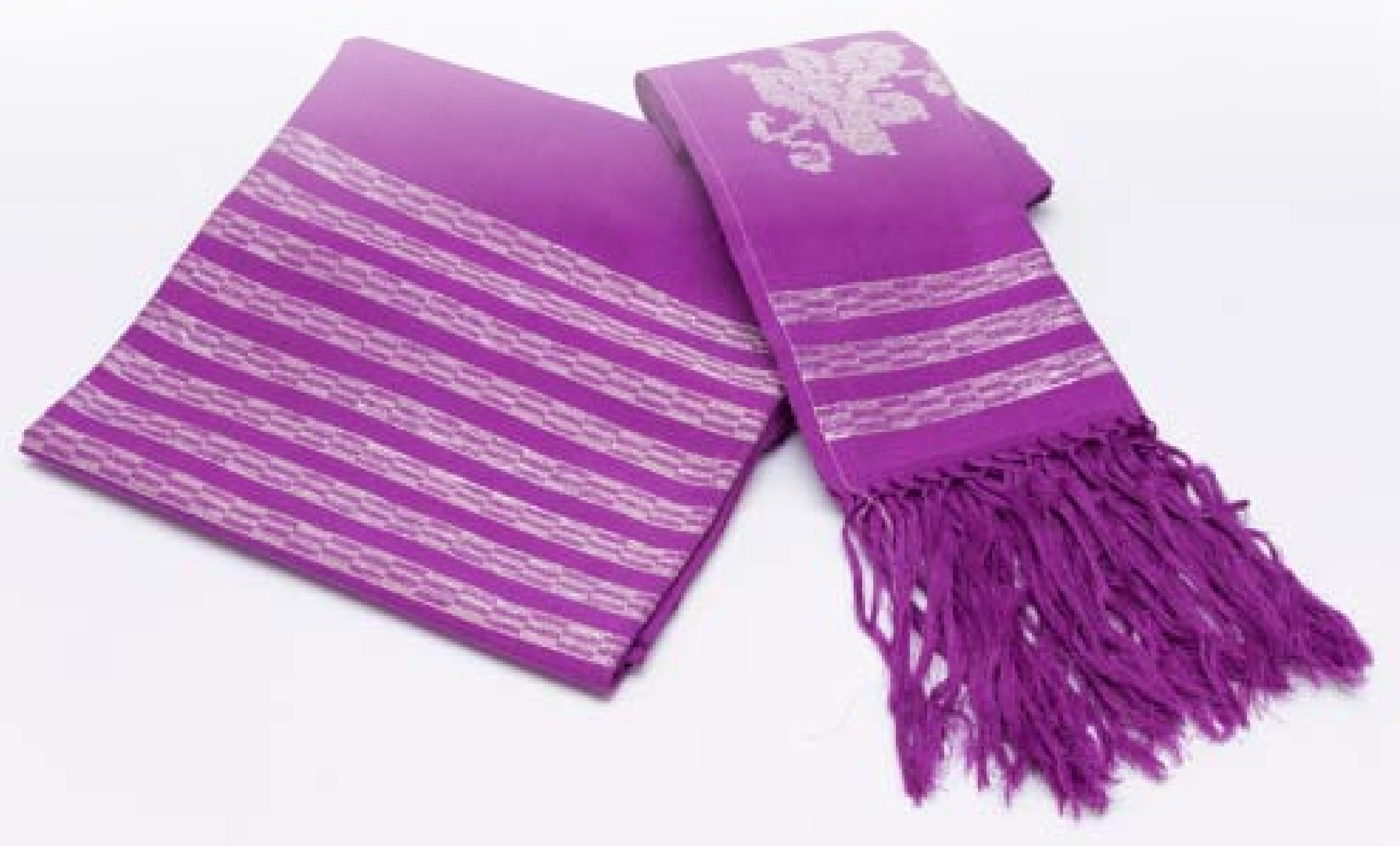

Tenun Panji adalah So'be Sumelang yang dibuat tidak melalui ikat atau songket, tapi dengan teknik anyaman langsung melalui benang pakan atau pasulu yang dianyamkan pada benang dirian. Hasilnya adalah ragam khusus sesuai dengan yang diinginkan melalui anyaman benang Tenun yang sudah diwarnai

Tenun Panji is So'be Sumelang that not made by tied techique or songket, but by woven the threads directly through Pakan or Pasulu thread interlaced on Dirian thread. The result is a special variety according to the desired through dyed woven yarn. 
Salur atau Jengki ditenun dengan

benang tembus depan dan be-

lakang berdasarkan pada hitungan langkah - langkah memasu-

kan dan menyisipkan benang.

Tenun Salur or Jengki with threads of translucent front and back based on a count of measures embodying and inserting the yarn.

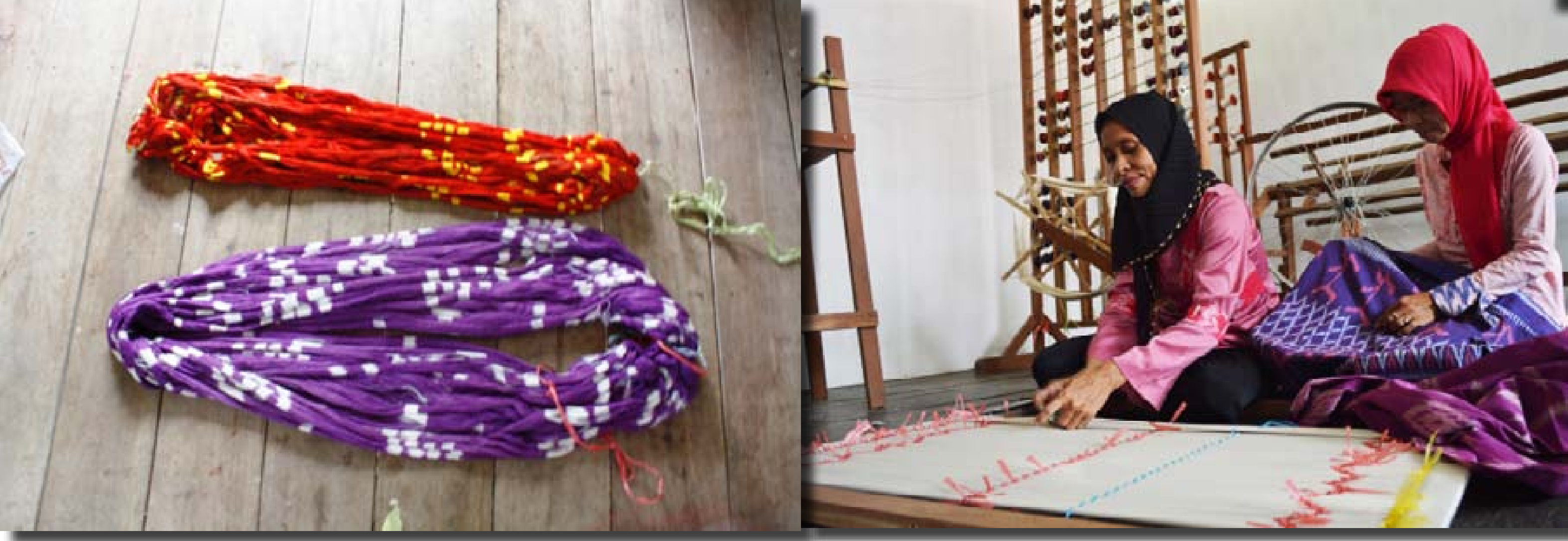

Tenun Ikat

Tenun yang dibuat dengan cara mengikat benang sebelum dicelupkan ke dalam pewarna alami maupun pewarna buatan.

\section{Tenun lkat}

Tenun made by tying the yarn before dipped in natural and artificial dyes. 
D $=0 \mathrm{ma}$

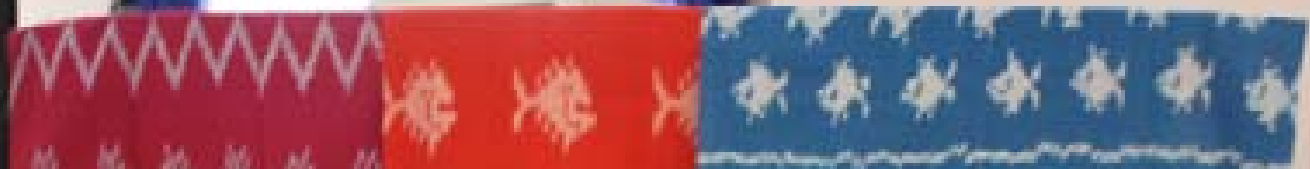

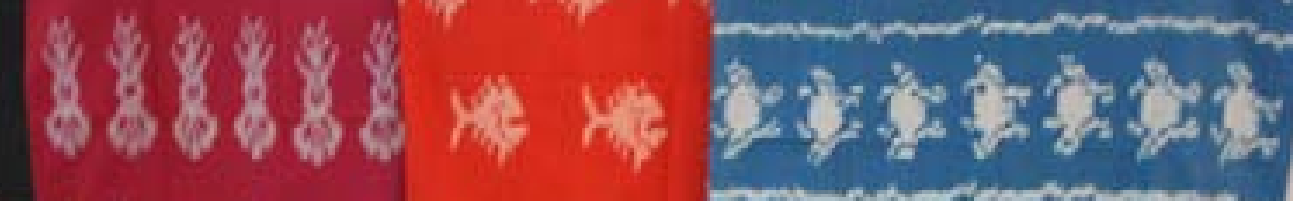
W.

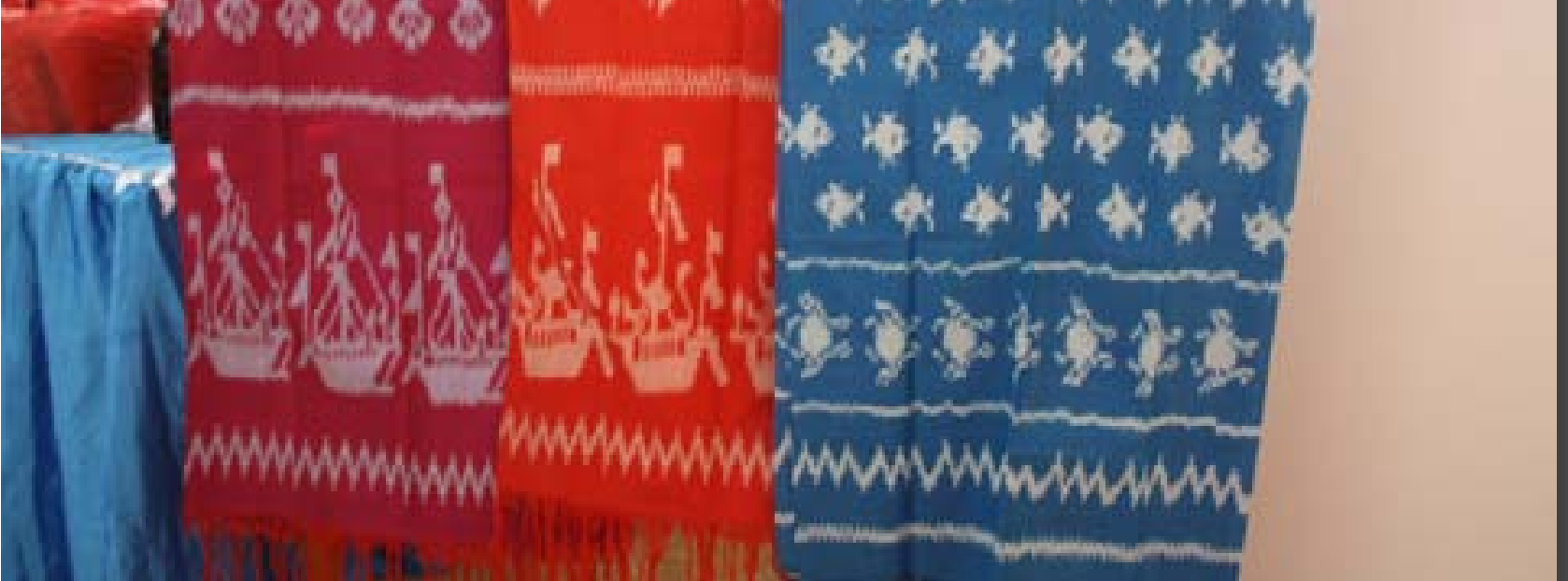

Tenun Ikat Pakan dan Ikat Lusi yang keindahannya ditentukan olah kepandaian penenun

Ikat Pakan and Ikat Lusi show its exquisite determined by brilliance skill of the weaver.

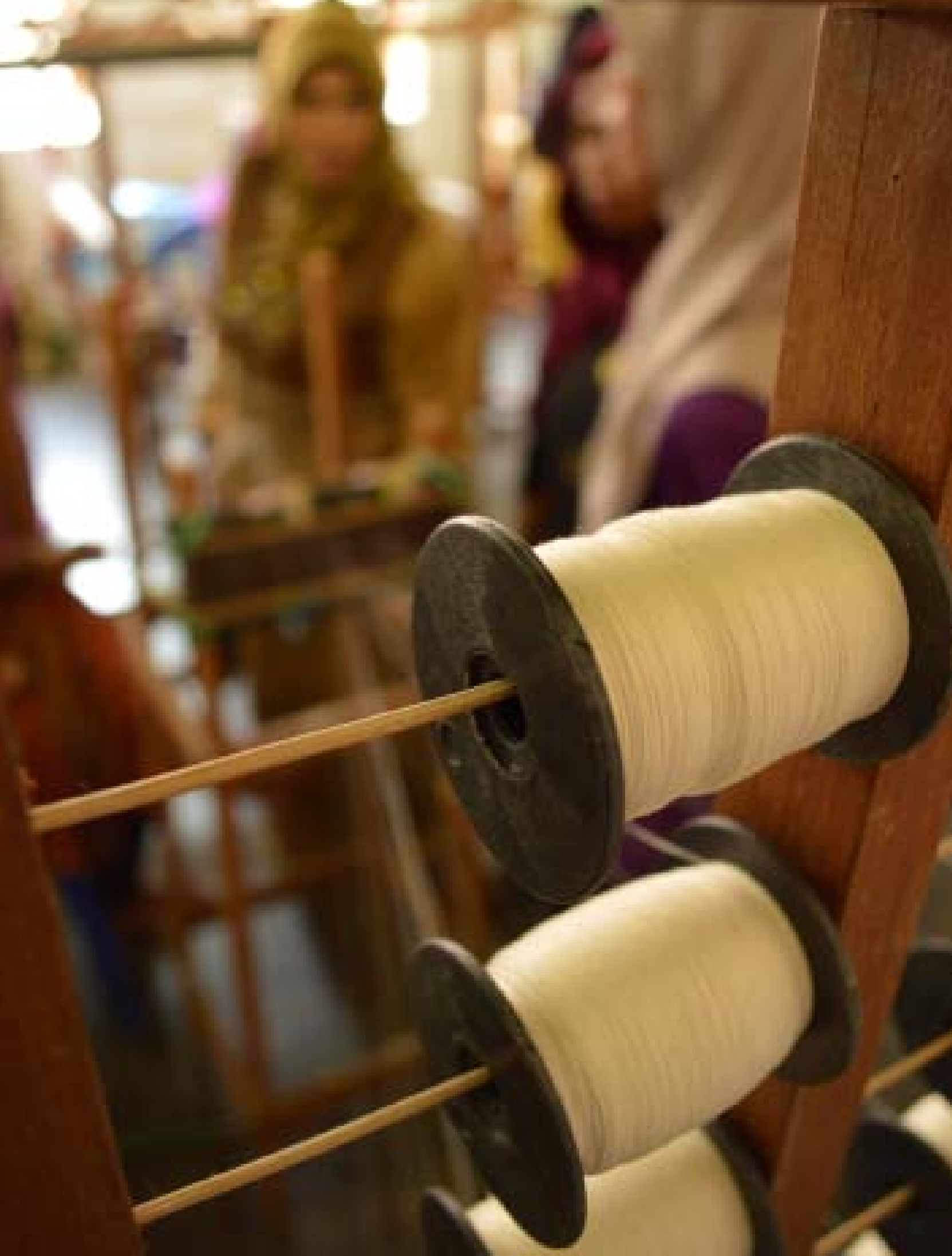

Rangkaian Sebuah Penciptaan

Sehelai Tenun melalui proses yang panjang oleh tangan tangan kreatif.

Tenun adalah hasil sebuah kerjasama.

The Sequence of

a Masterpiece

Piece of Tenun has been through a long process by creative hands. Tenun is a result of cooperation. 


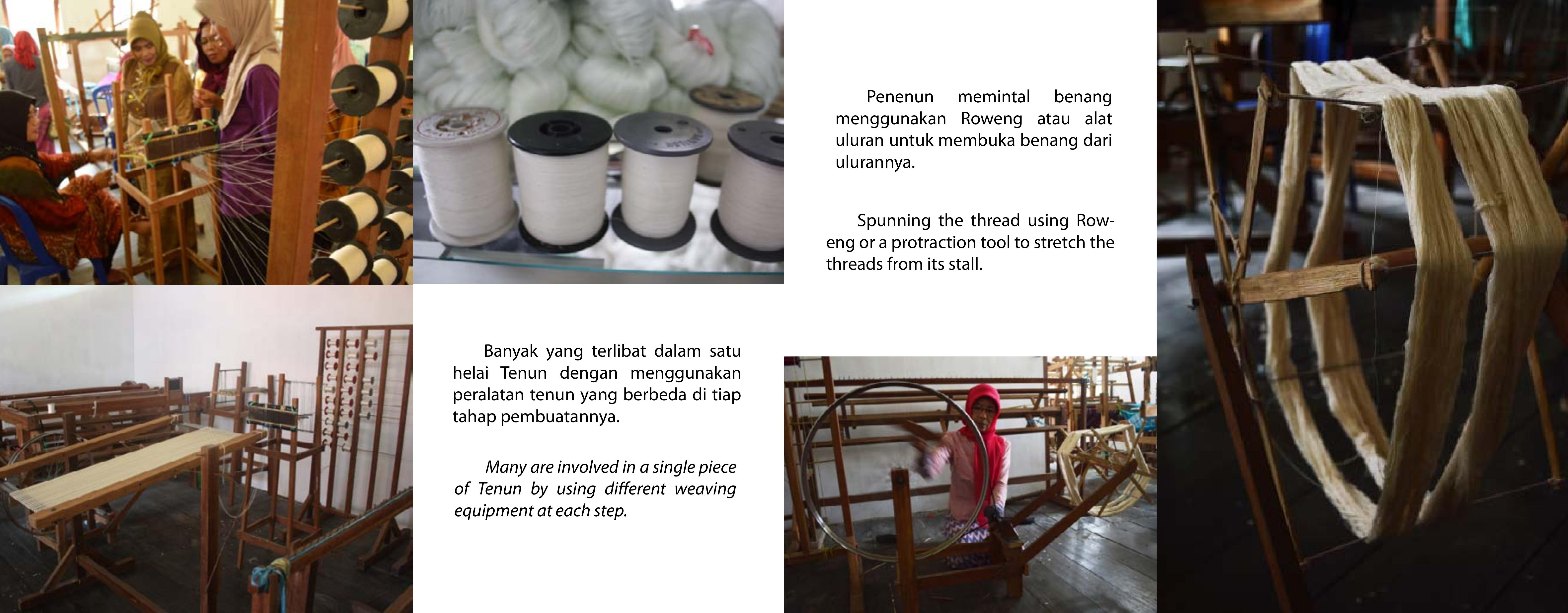



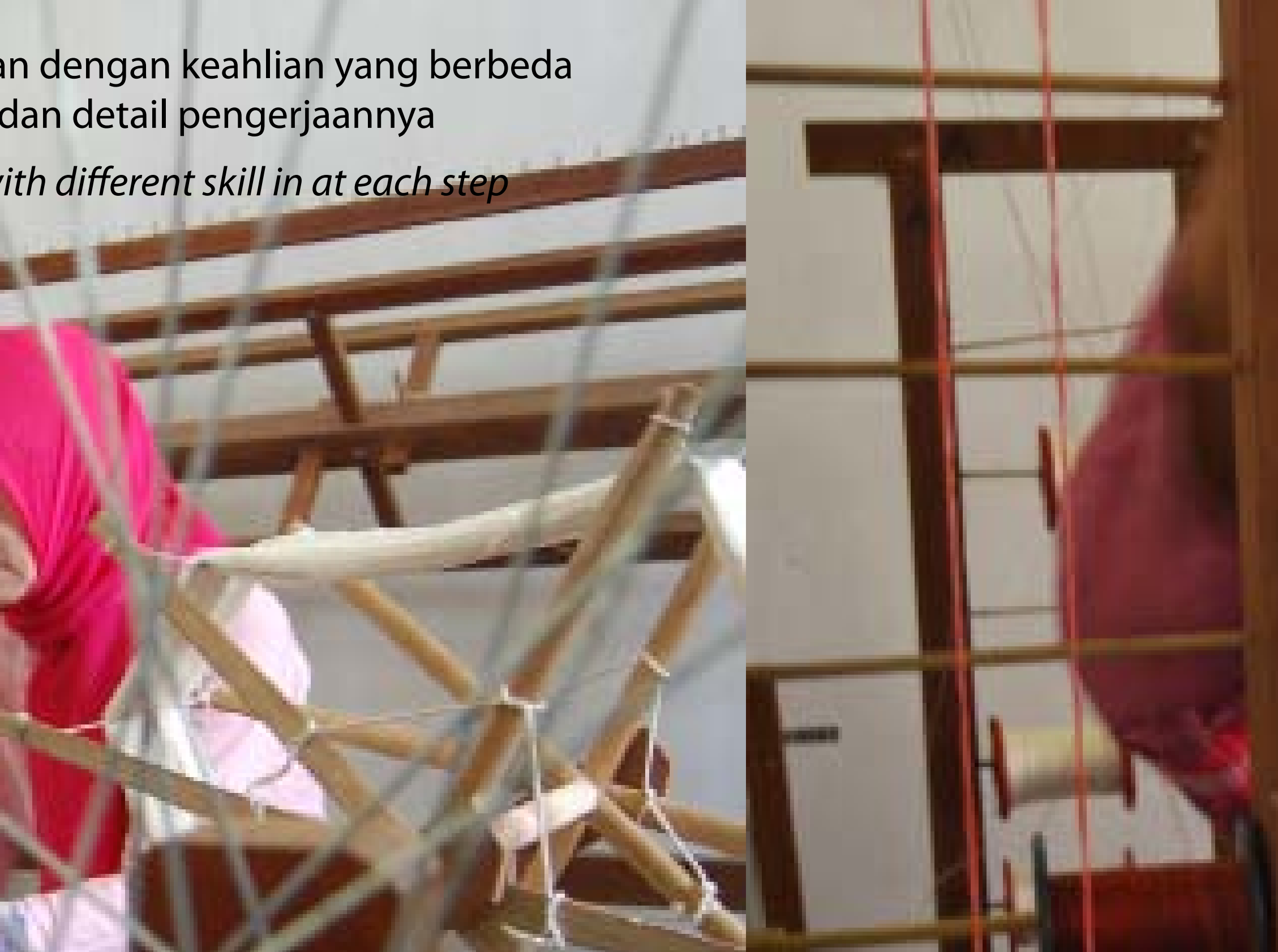

Can

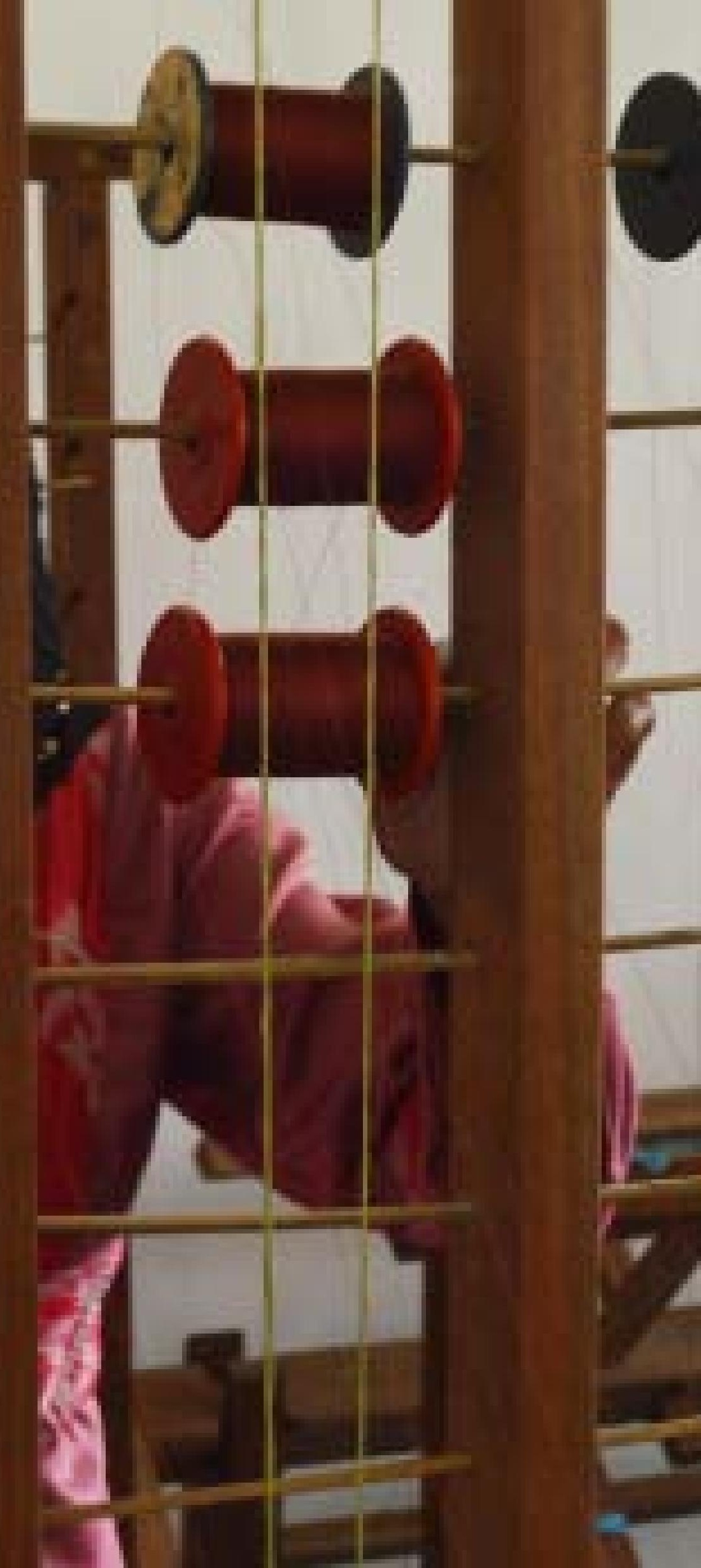




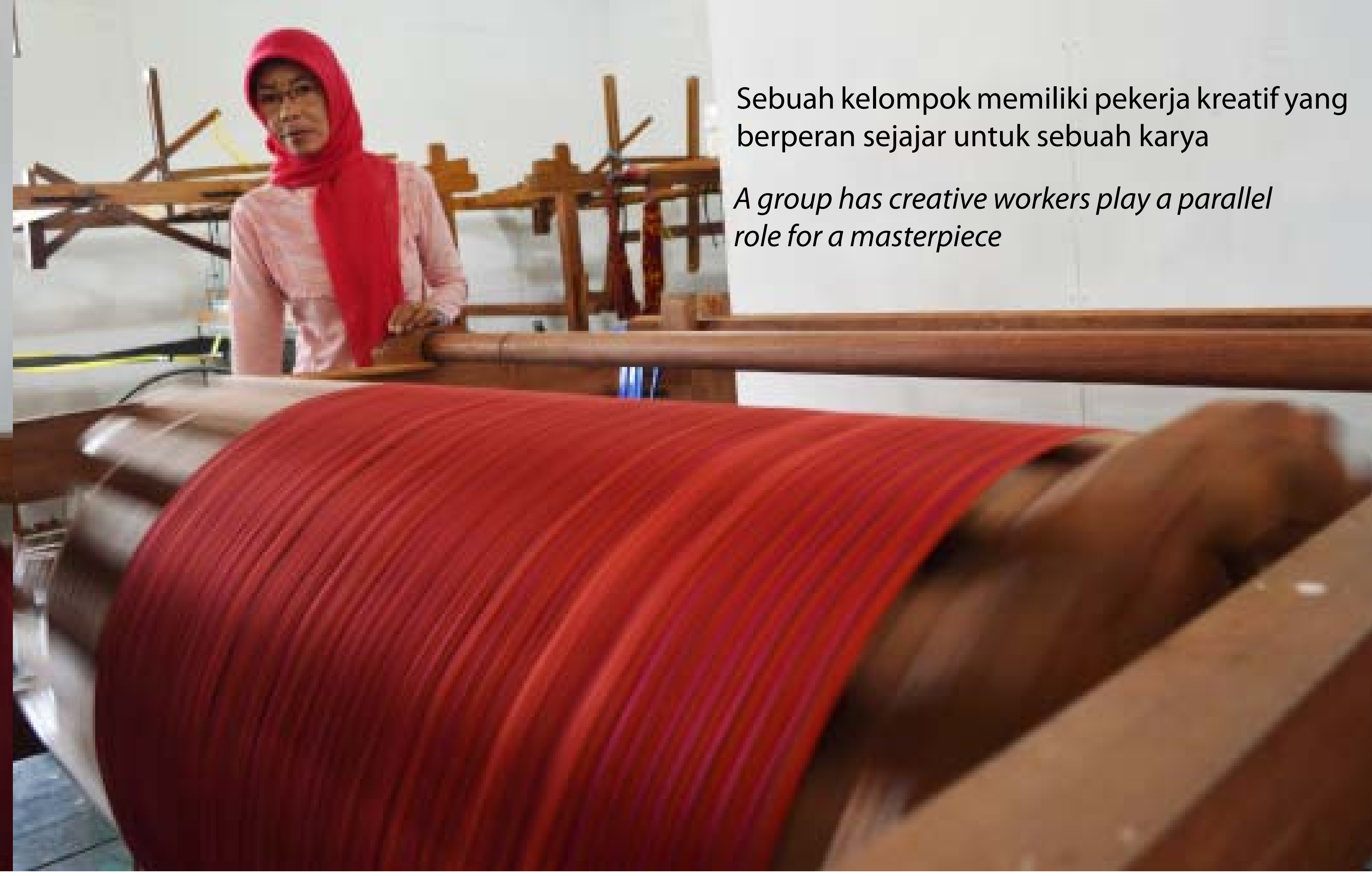




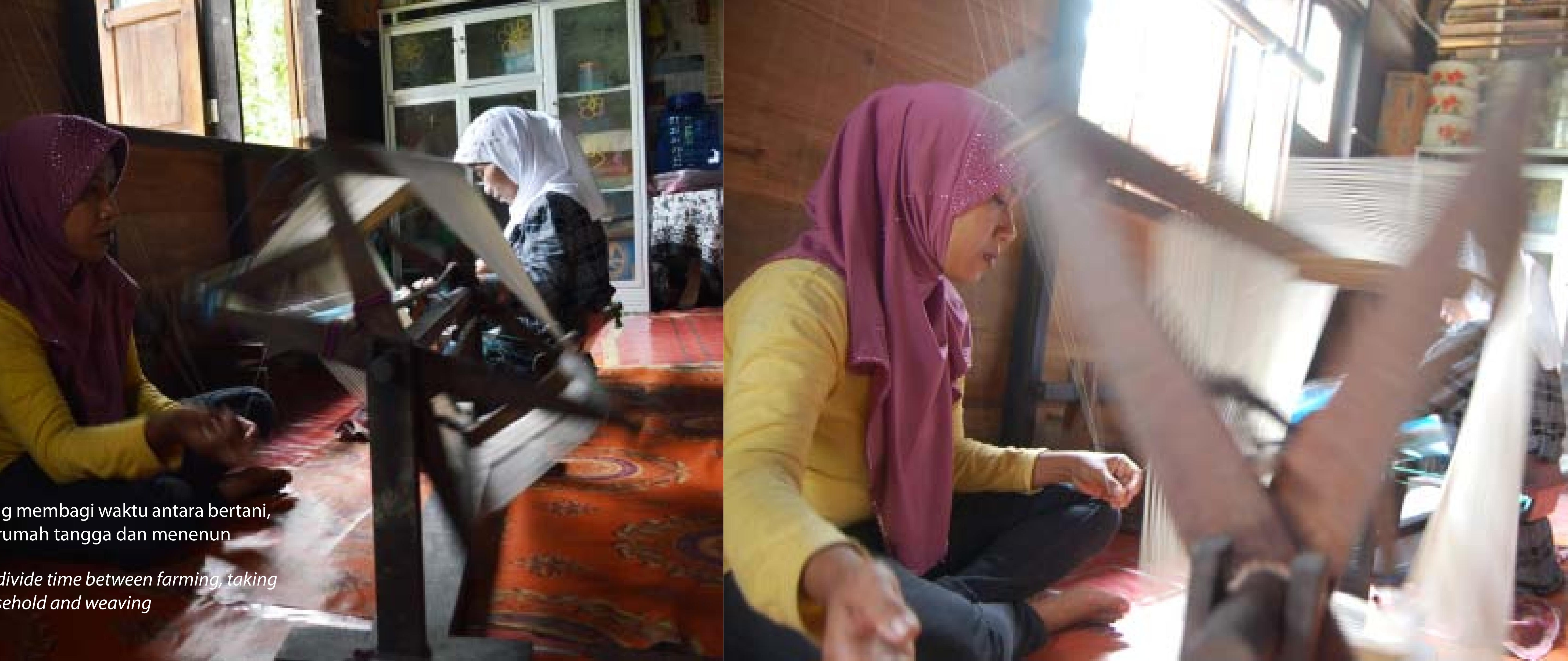




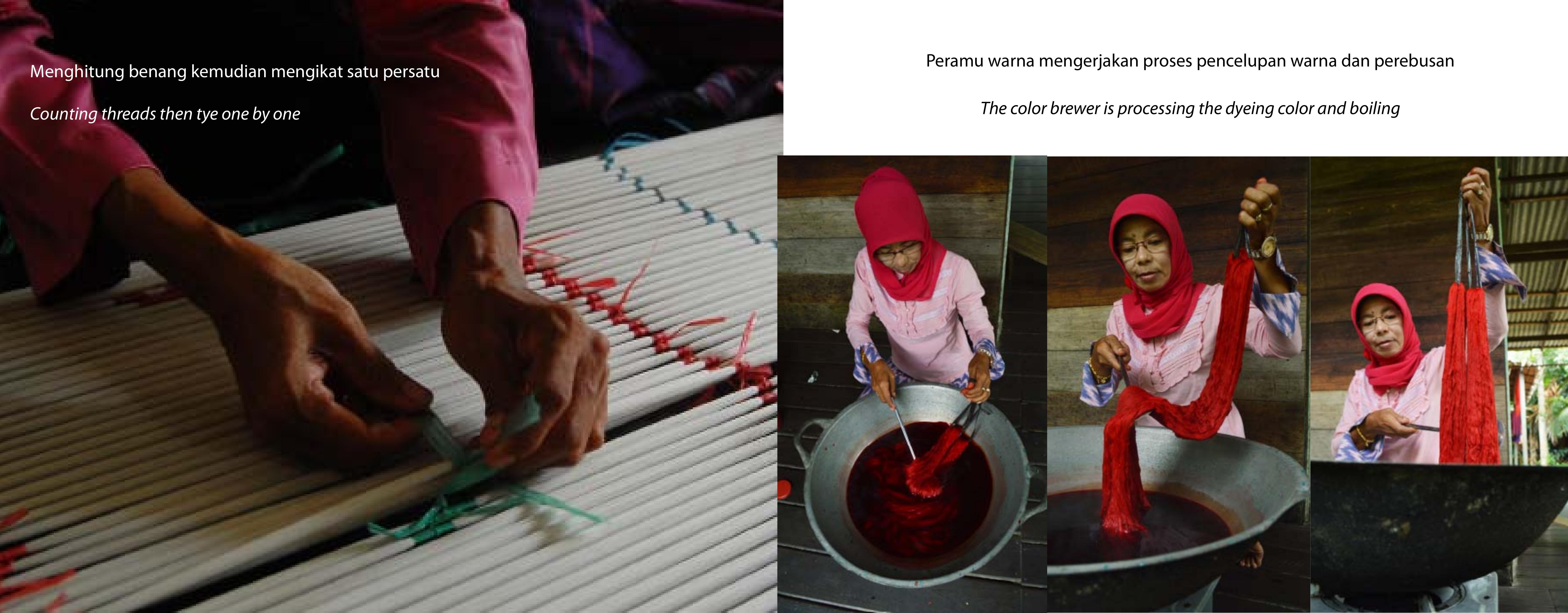


Keceriaan warna-warna pada Tenun Pagatan ditentukan oleh peramu warna

Cheerful colours on Tenun Pagatan determined by the brewer
Perpaduan warna yang menambah semaraknya tenun

The mixture of colors makes Tenun more cheerful

G.
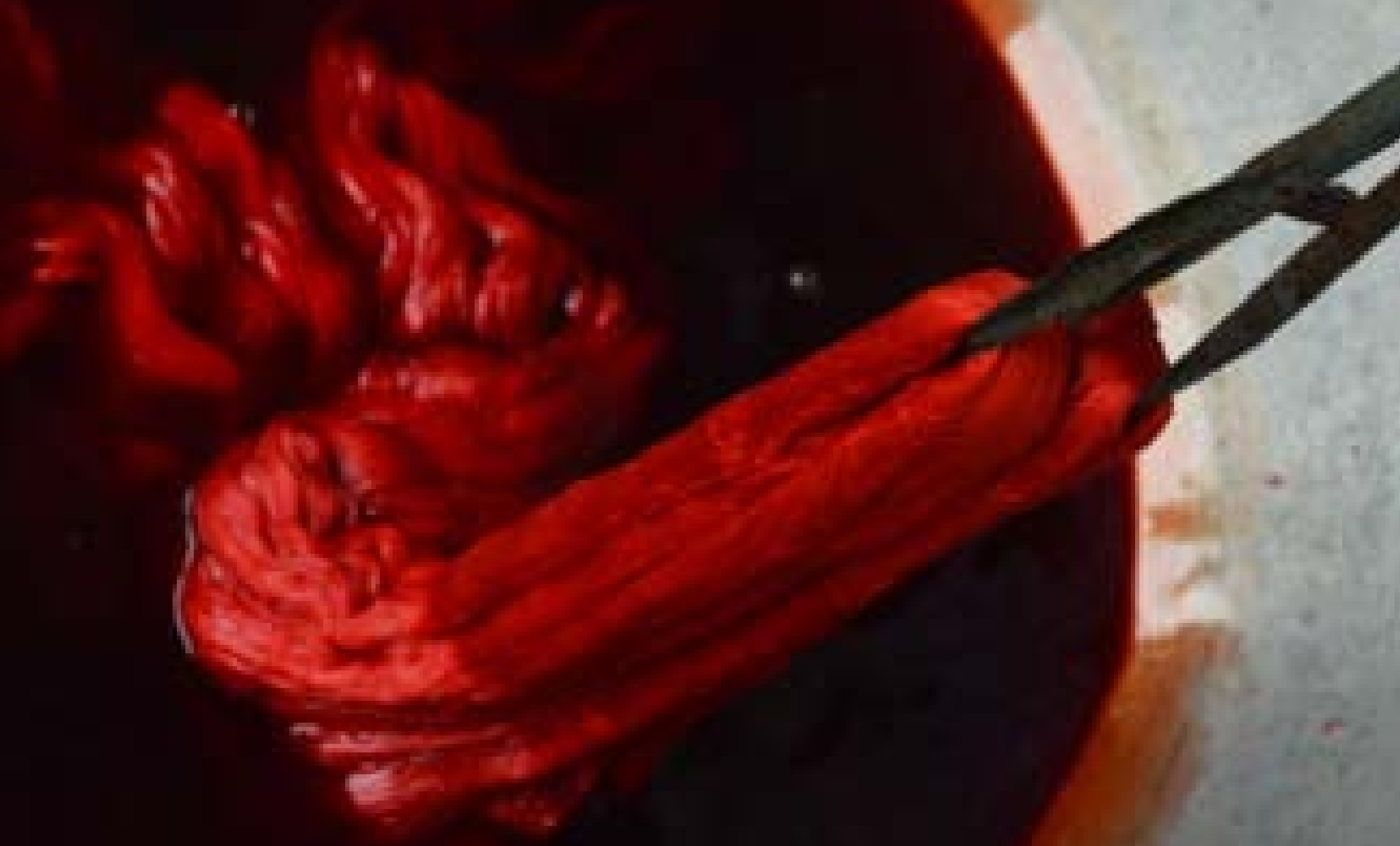


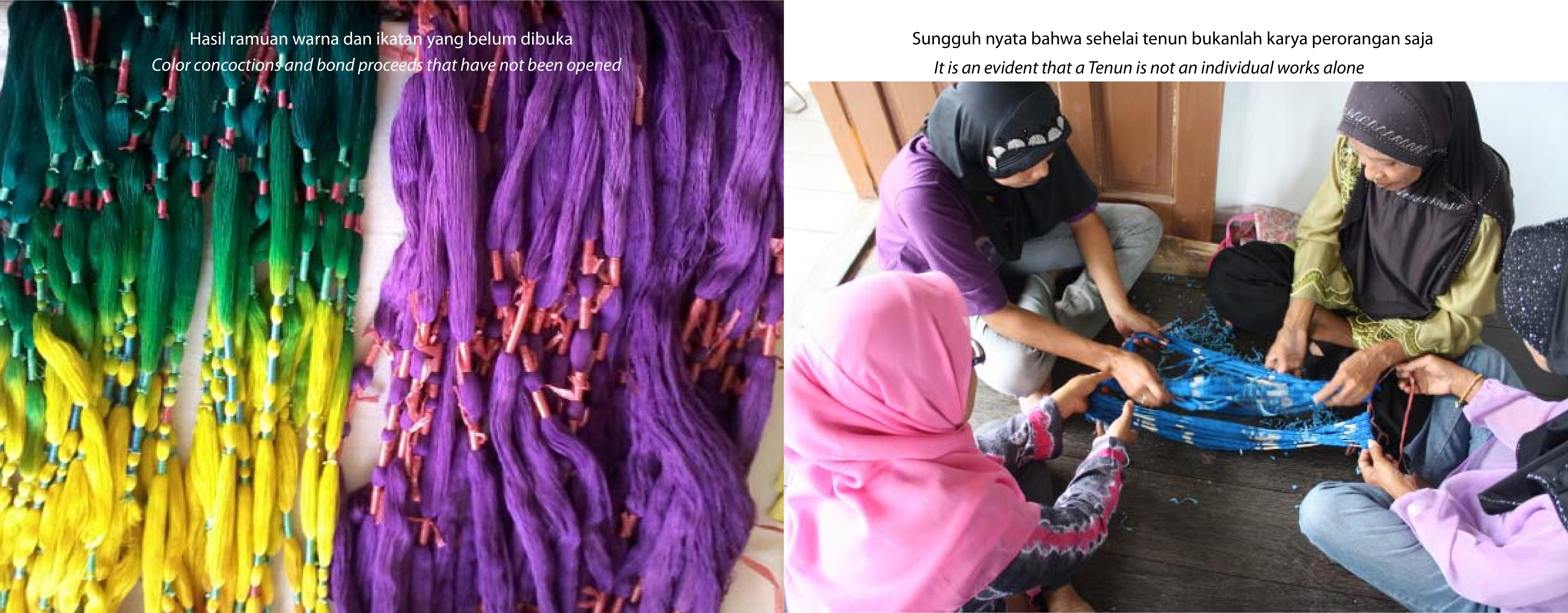




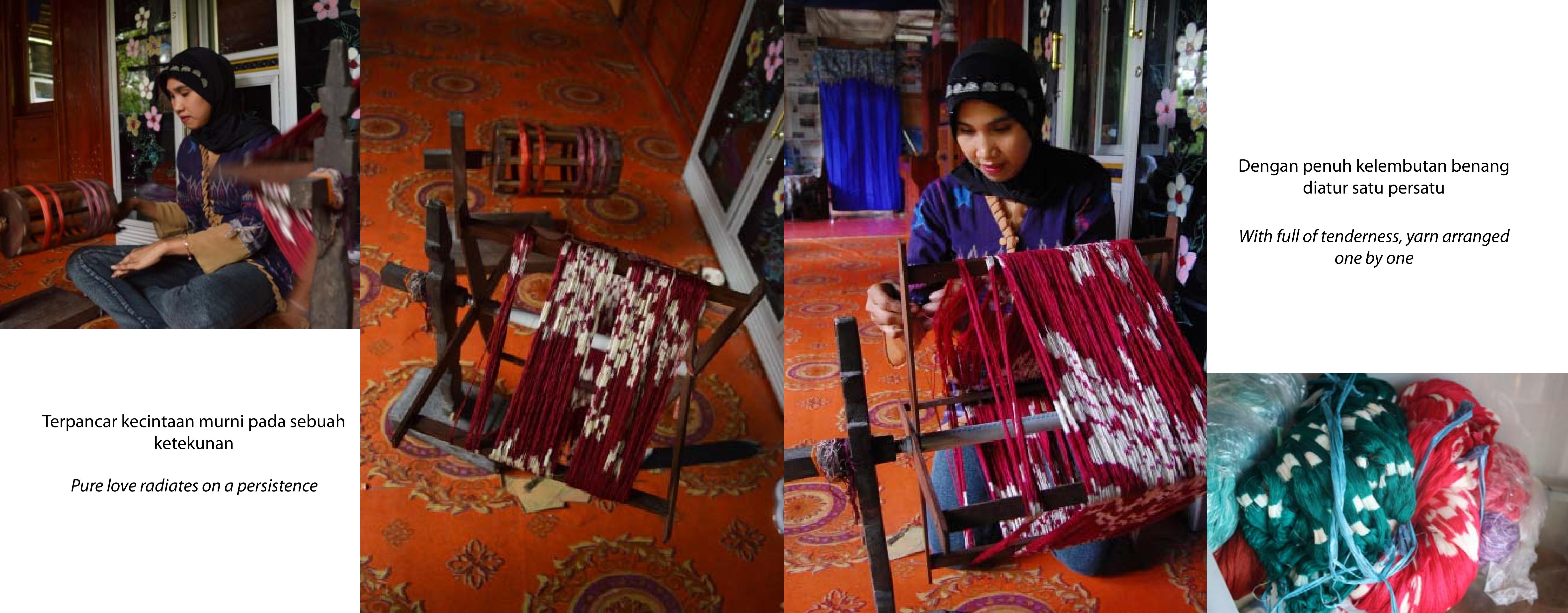




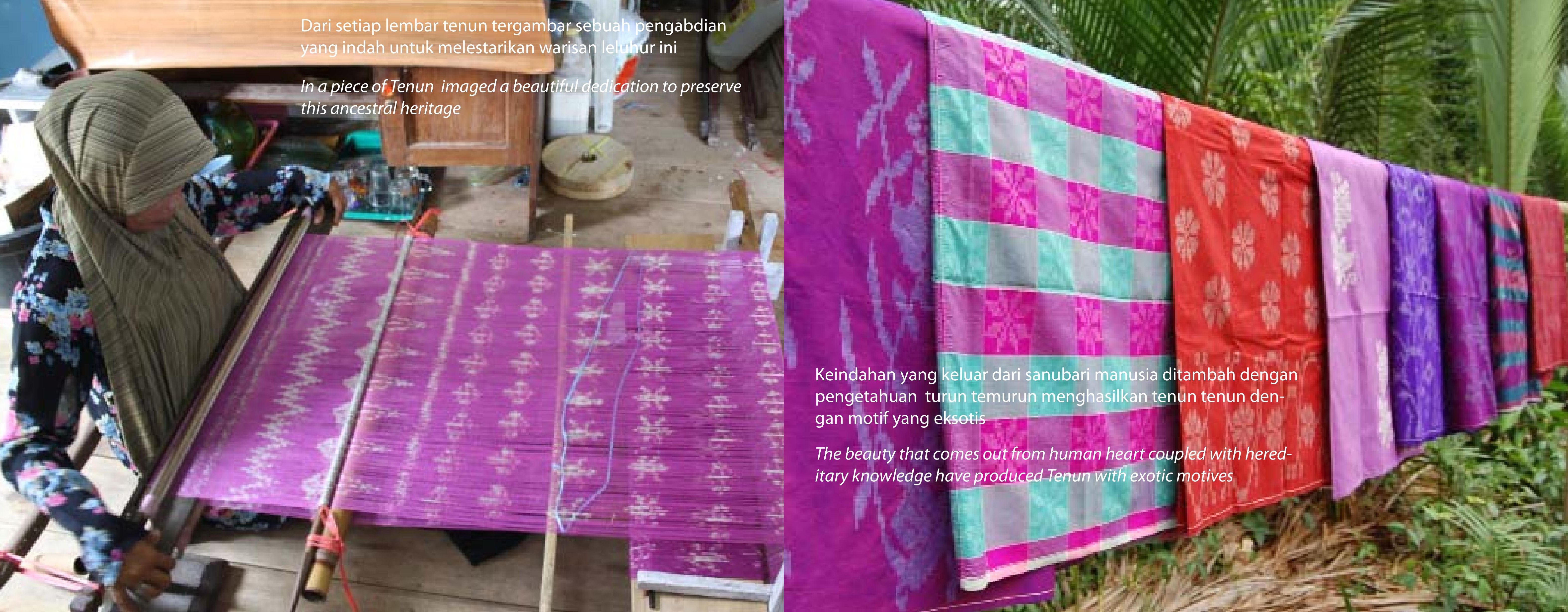


Proses menenun dilakukan dengan cara mengatur benang Tenun sesuai dengan ikatan pada waktu benang dicelupkan ke dalam pewarna. Dan jadilah sebuah ornamen sesuai dengan corak yang diinginkan oleh penenun.

Weaving process done by organizing yarn in accordance with the ties when thread dipped into dye. The result is an ornament according to weaver's desired pattern.

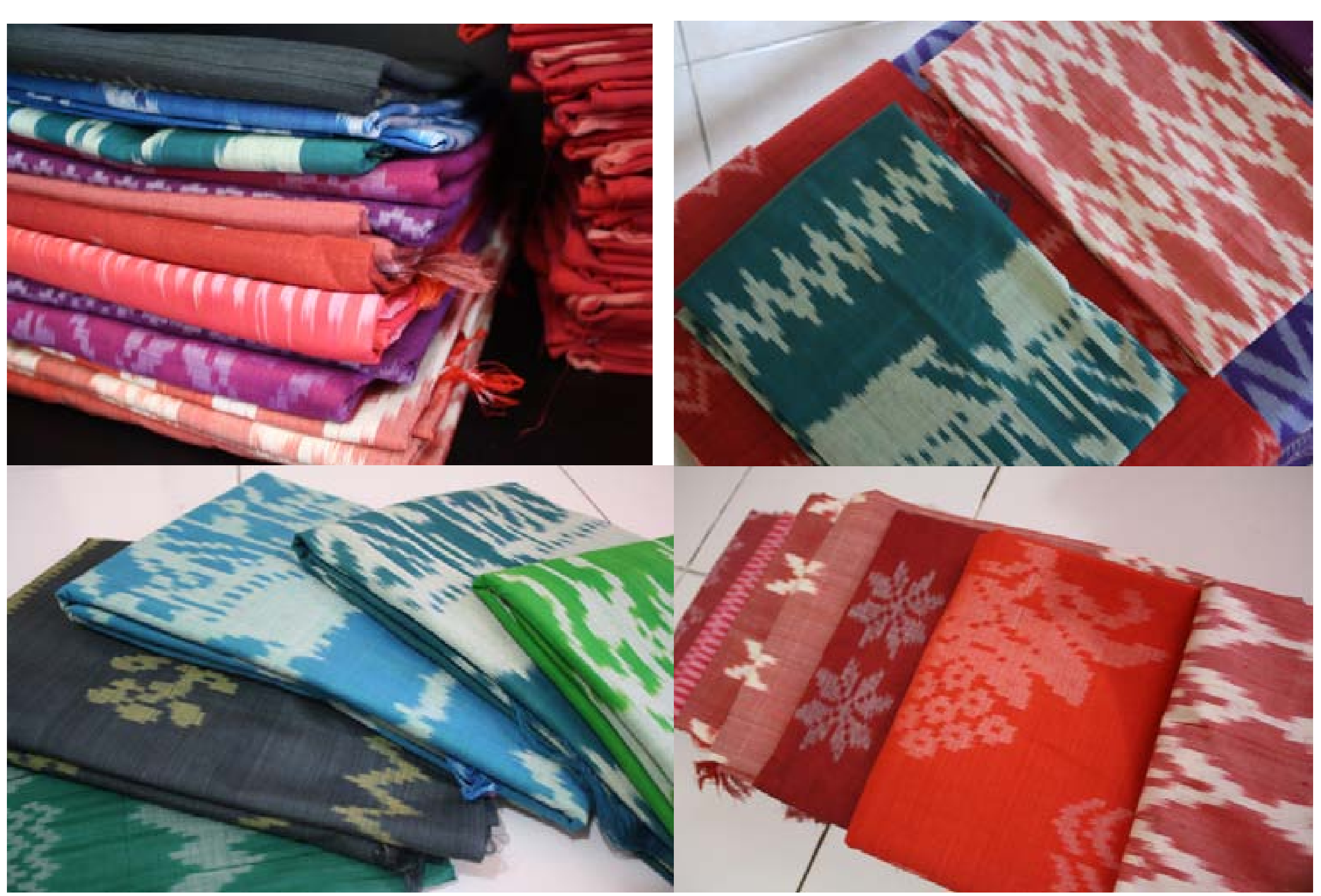

\section{Inspirasi dari Alam}

Tenun Pagatan mempunyai pola dasar yang kemudian menjadi acuan dalam menenun. Pola tersebut adalah Gelombang, Rantai dan Janur sebagai ciri khas Tenun Pagatan yang membedakannya dengan Tenun lain di Nusantara.

\section{Inspiration from Nature}

Tenun Pagatan has base patterns that later become reference in weaving. Such patterns are Gelombang - Wave, Rantai - Chain and Janur - Young Coconut Leaves, different compared to other Tenun in Indonesia archipelago. 
Rajutan benang menjadi ikat. Tenun ikat Pagatan mengilhami kehidupan, mengalir seperti sungai lalu bermuara kelaut. Riak-riak yang membentang dipasir putih. Motif pohon Bakau tegar menanti hempasan gelombang.

Knitted yarn into Tenun Ikat. Tenun Ikat Pagatan inspiring life, flowing like river and ending to the sea. Ripples extending on a white sand. Motif of mangroves unruly awaits the crashing waves.

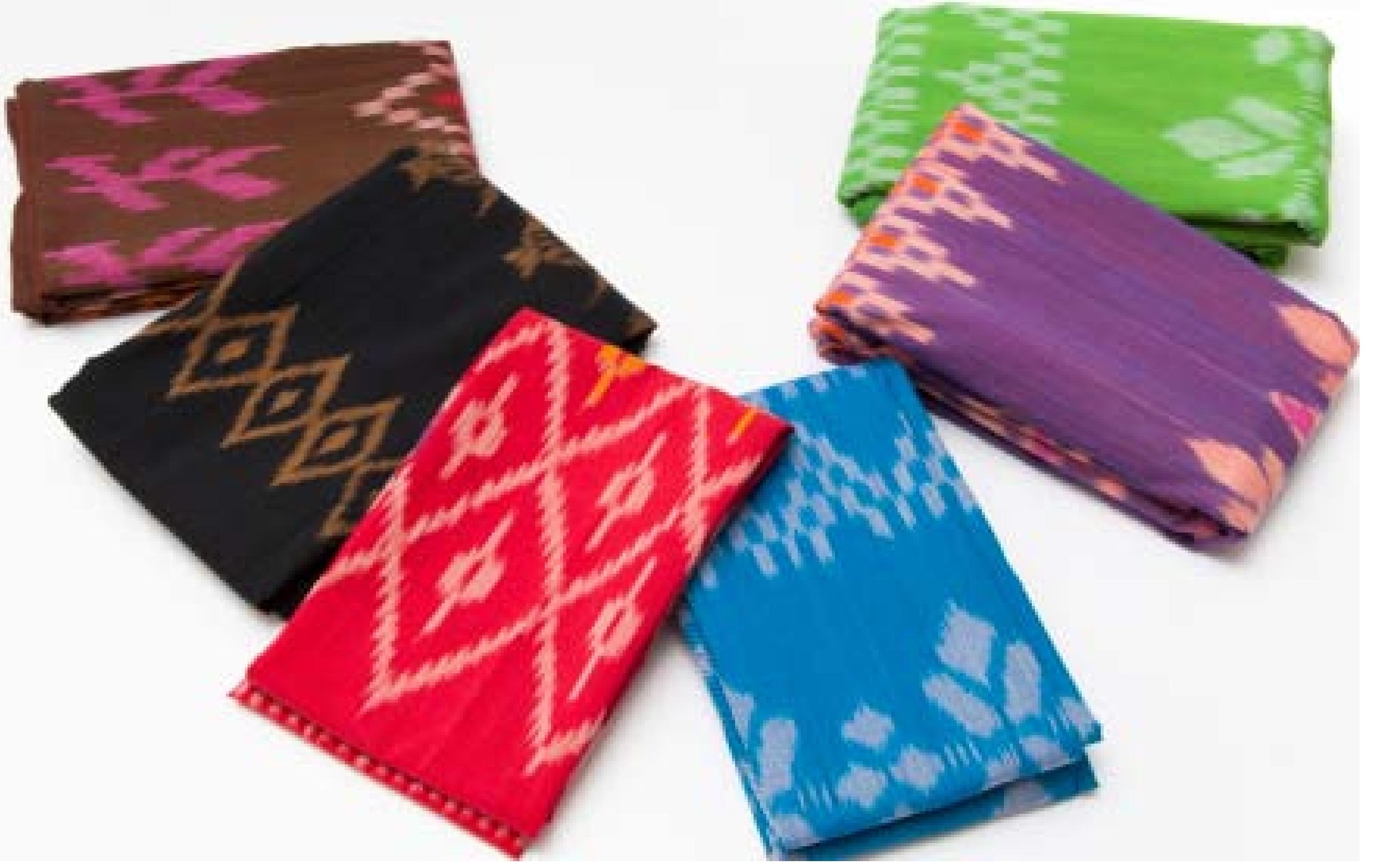

Inspirasi penenun tentang laut dengan berbagai terumbu karang yang kokoh dan indah tempat berselindung ikan-ikan, menambah suasana romantis kampung Nelayan Pagatan

The weavers' inspiration about sea with variety of sturdy coral reefs and beautiful place for fish to shelter adding romantic atmosphere of Pagatan's fishing village

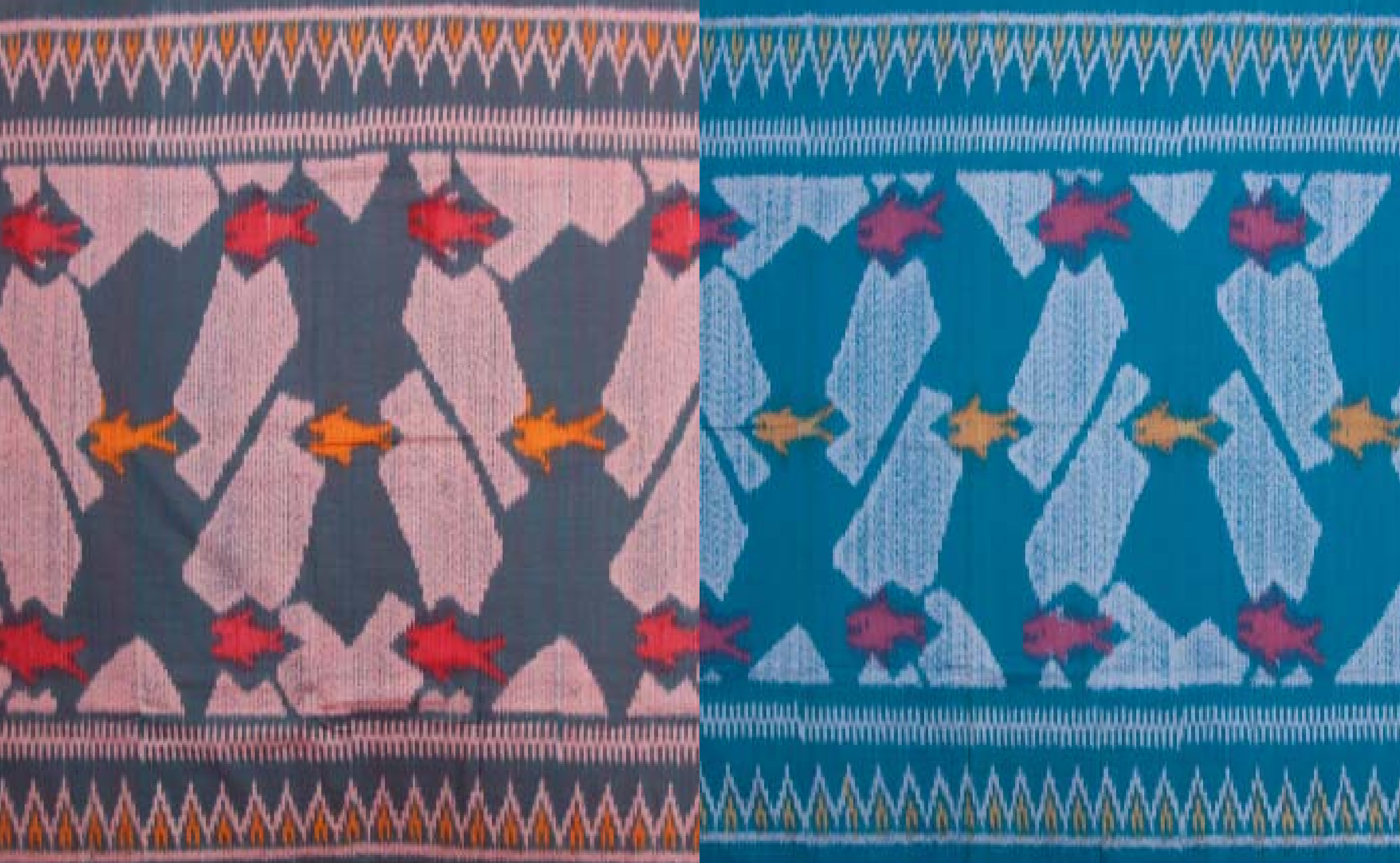




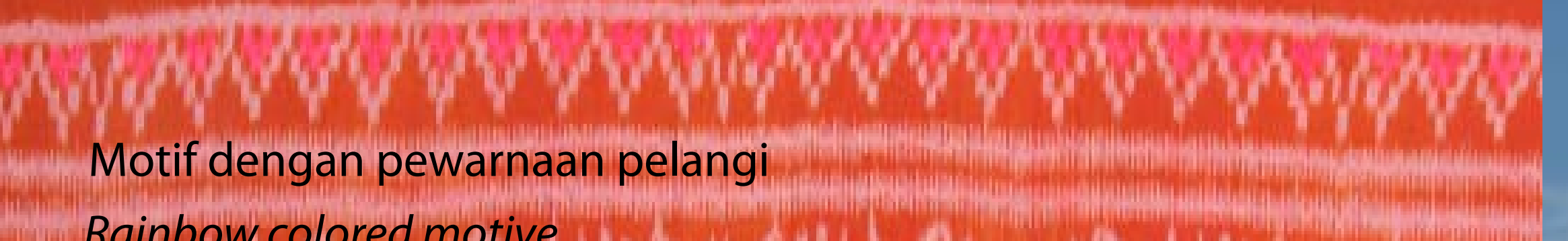

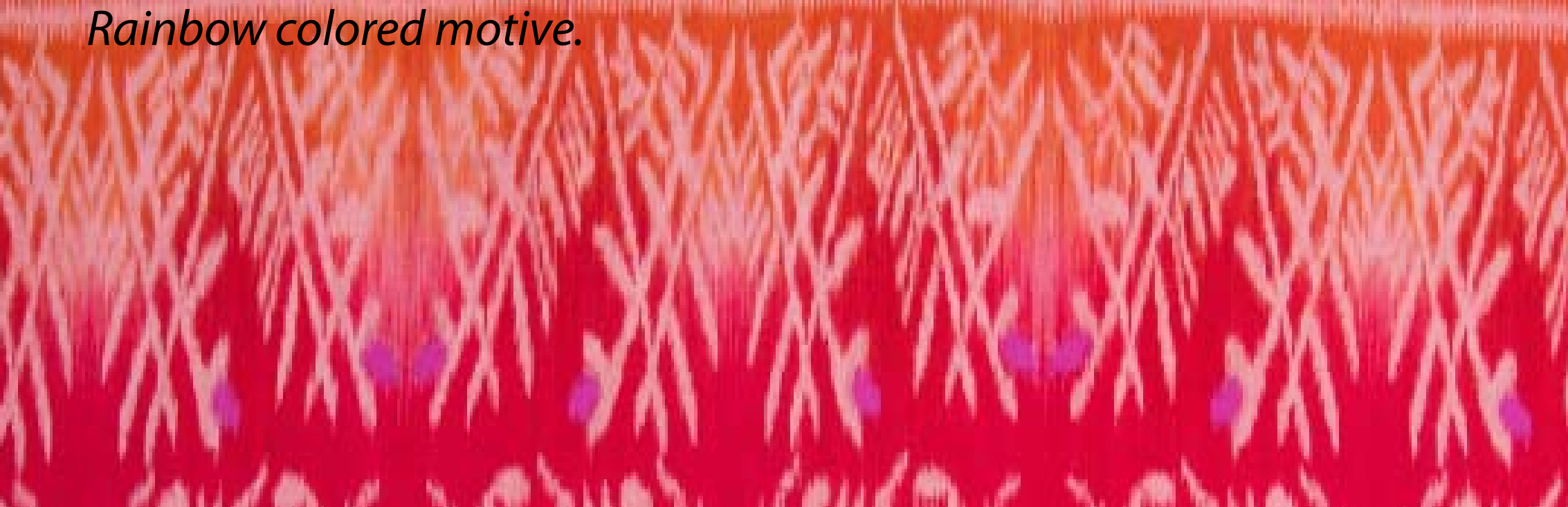
Whith (2)

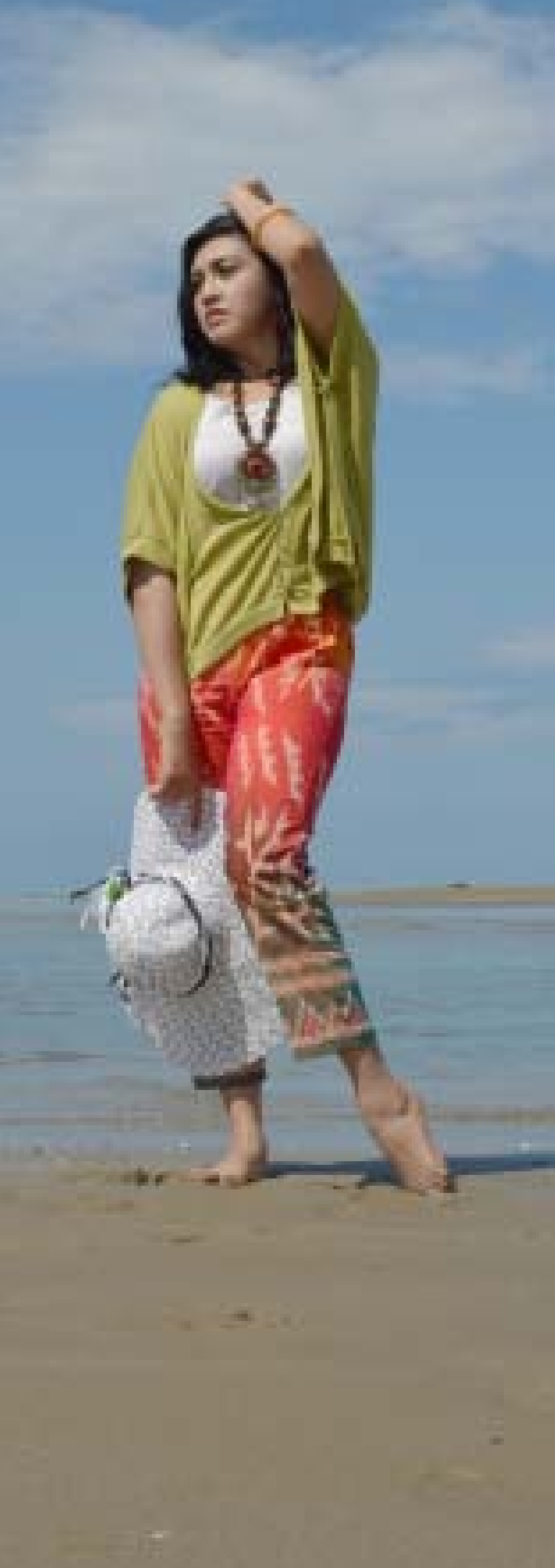

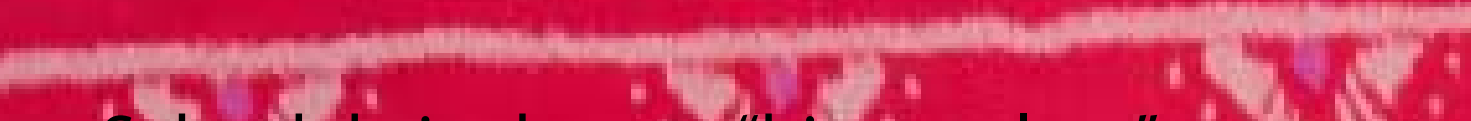
A fabric with "seastar" "which shine forth among the waves that hit the shore." :

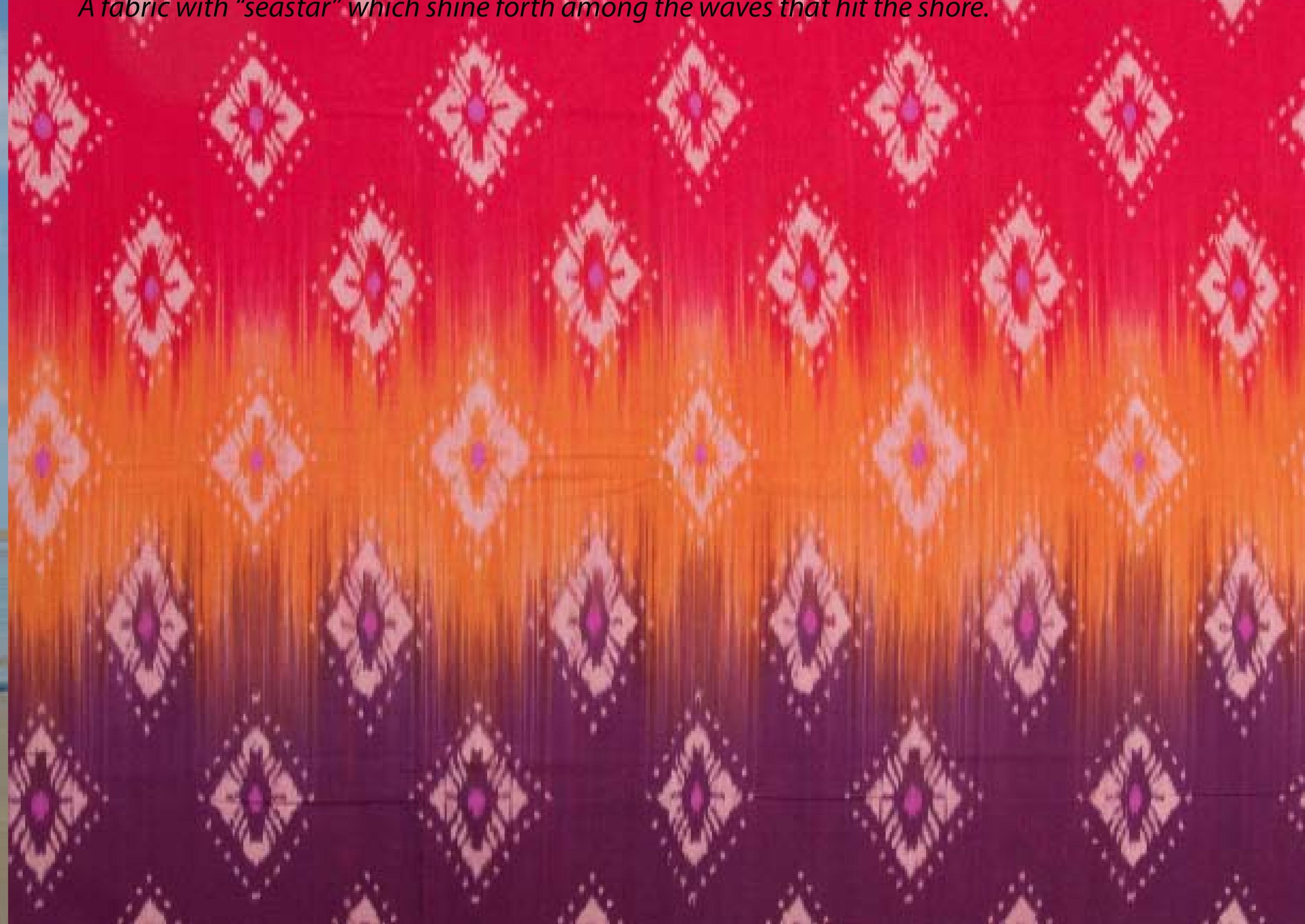

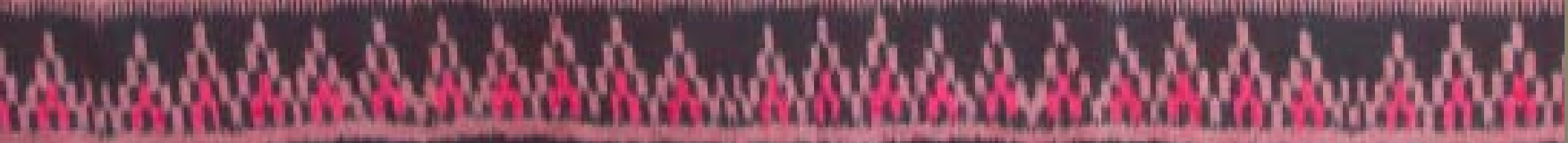
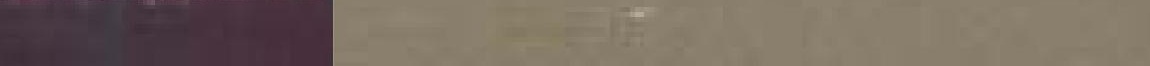


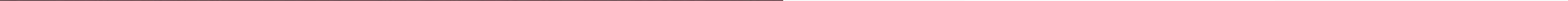


Sederhana tetapi mempesona, beginilah alur-alur benang yang sangat dekoratif. Warna "merah muda" dan "oranye" ditengah Rantai ini memberi kesan tentang kekaguman penenun pada pentingnya sebuah kombinasi.

Simple yet stunning, this is groove of decorative threads. The "Pink" and "Orange" color in the middle of these chains give impression of weavers' admiration to the importance of a combination.
Cita rasa yang diolah dengan sentuhan budi dan daya kreatif penenun menghasilkan keindahan corak nan alami

The flavors mingled with a touch of kindness and creative power of the weavers produce a natural beautiful complexion

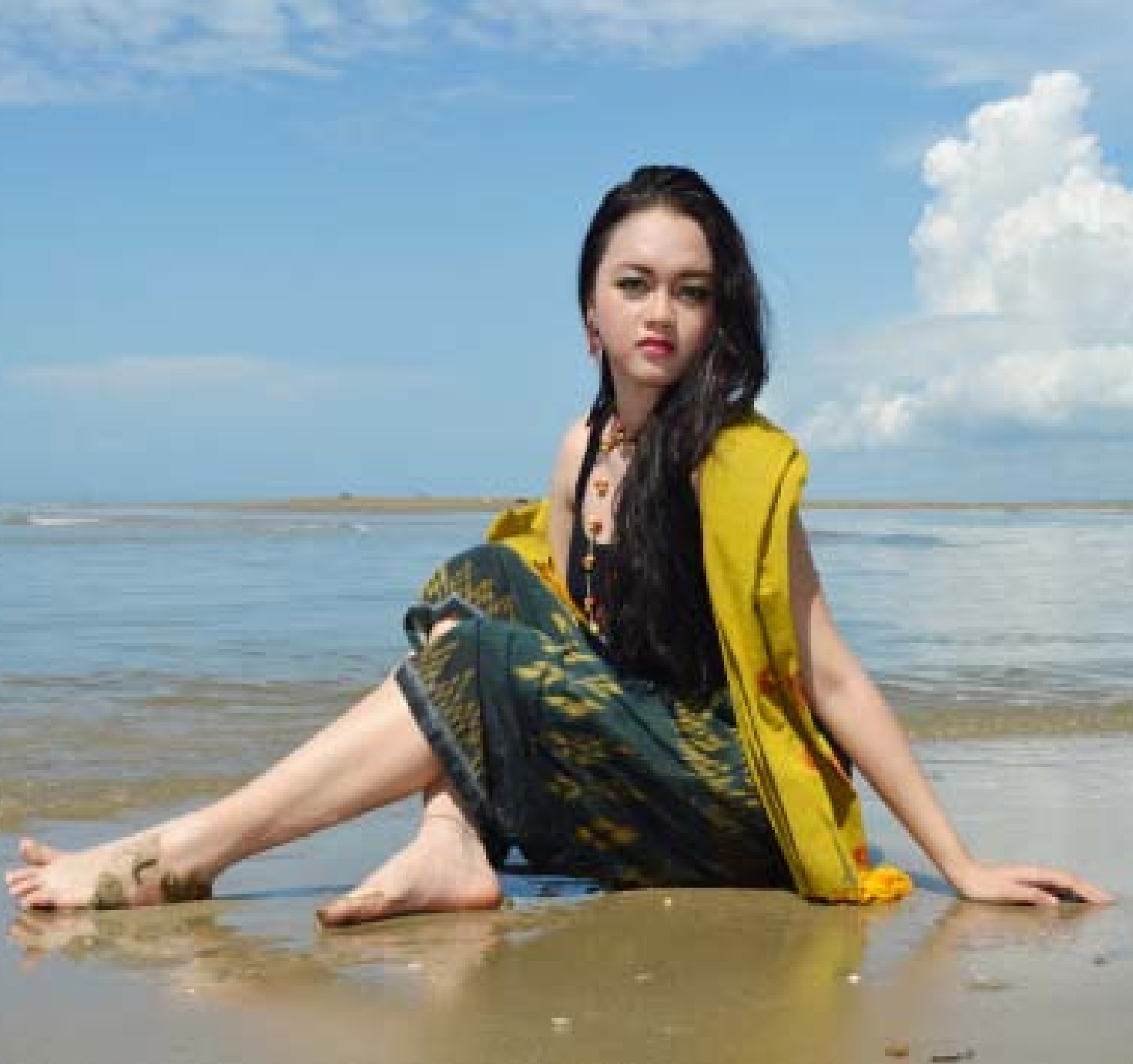



yang apik, keterpaduan garis simetris membentuk sebuah bangunan yang kokoh.

Tenun Ikat's charm, like an epic dance, symmetrical lines forming an alignment of sturdy building.
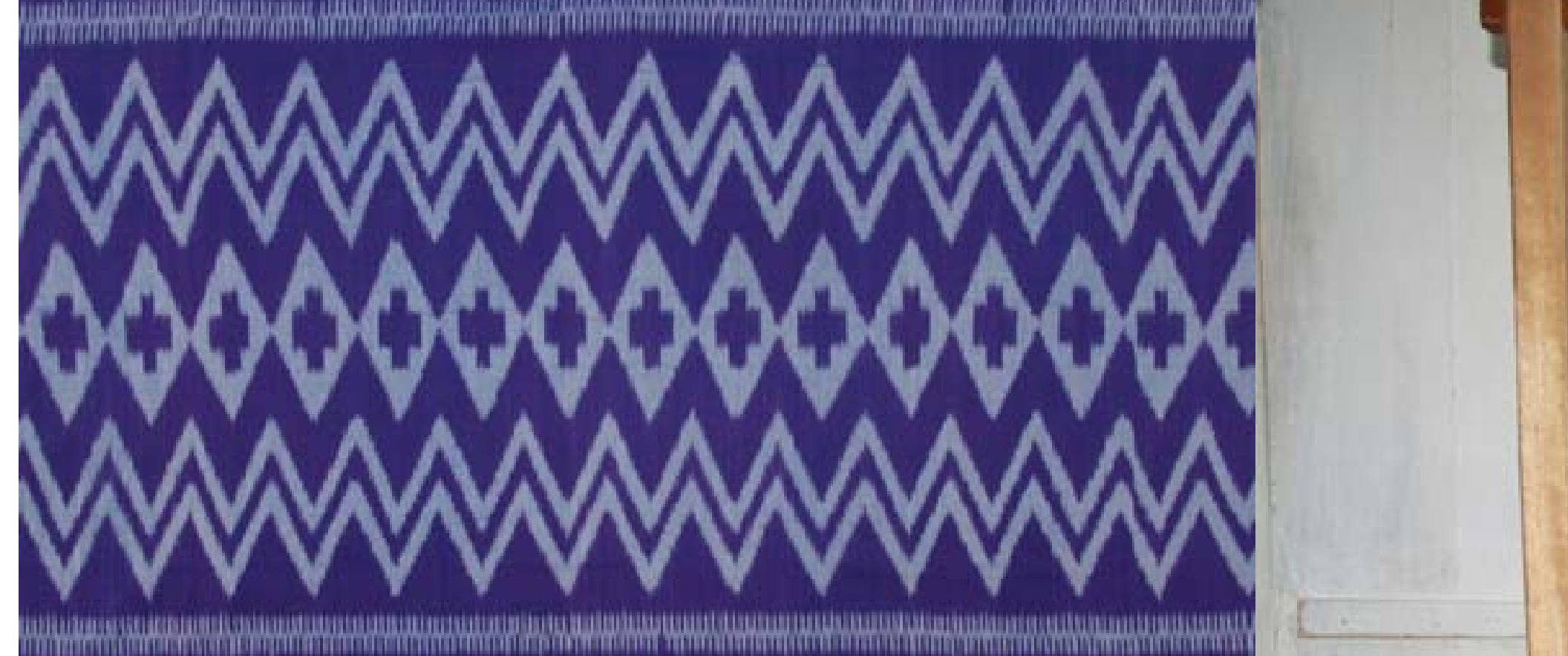

(1) WWWWWWWWWWWWMOWWWNWWWWW

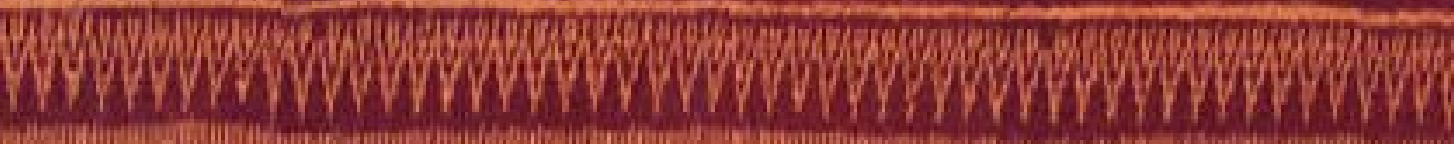
MMMMM WWWWWWW

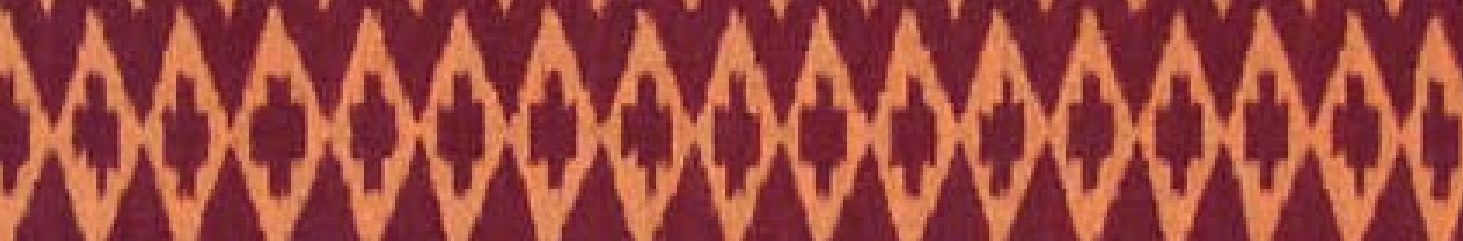
MWMMWWM WWWWWW

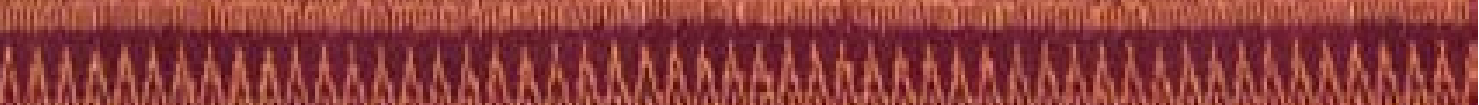


Tenun ikat yang memperlihatkan garis simetris dipadukan dengan motif flora dan warna lembut Tenun Ikat showing symmetrical lines combined with soft colors and floral motives.

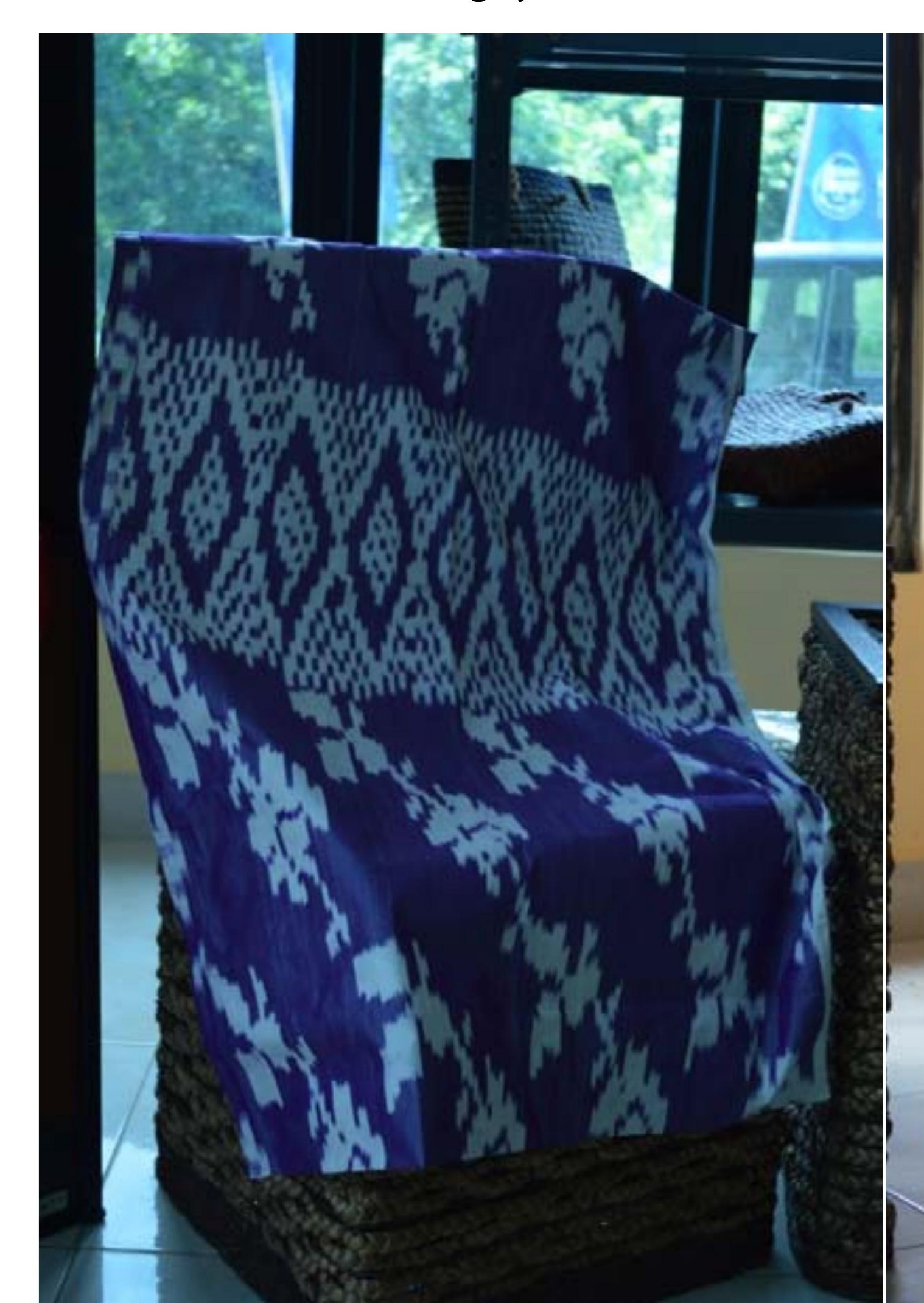

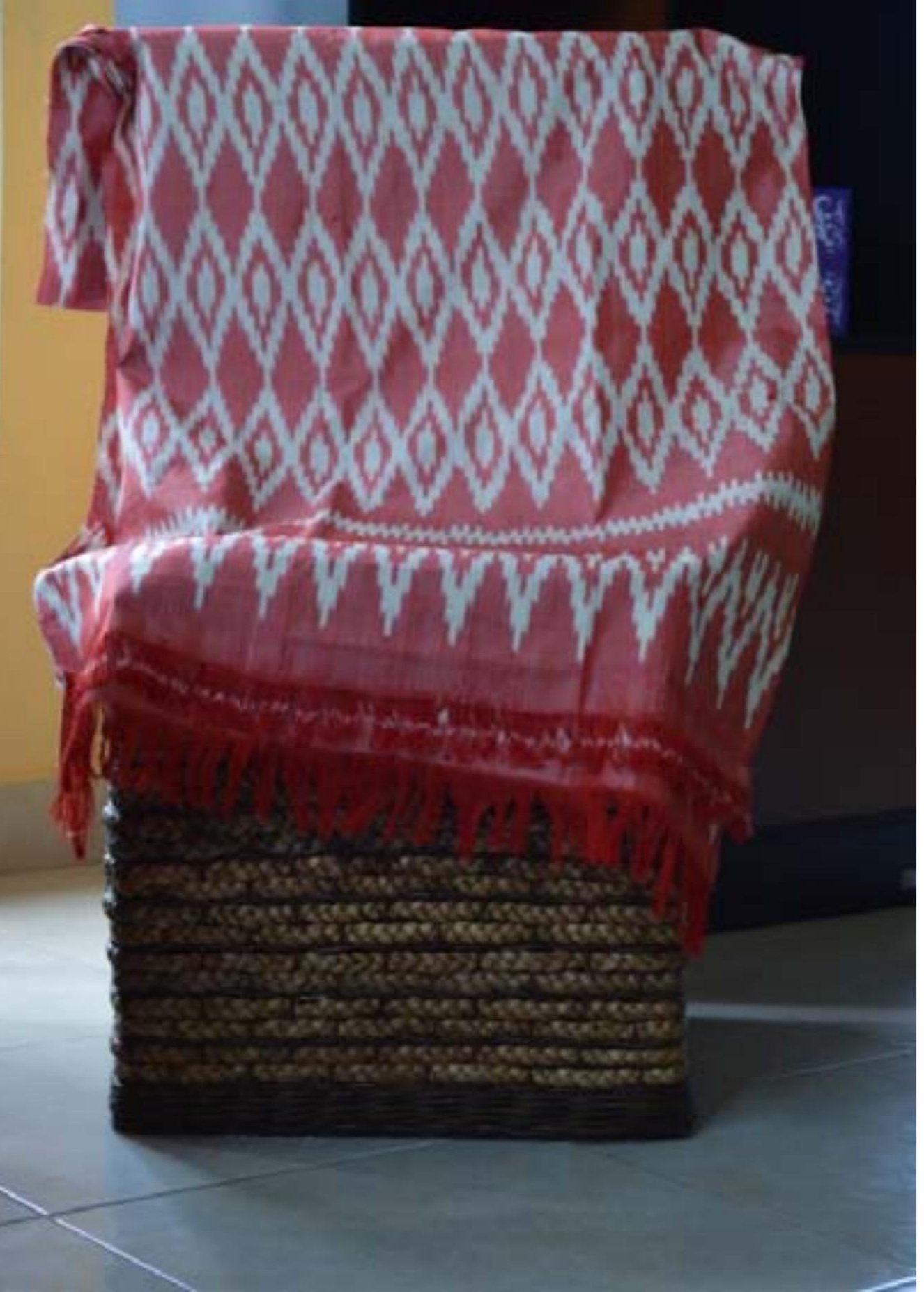

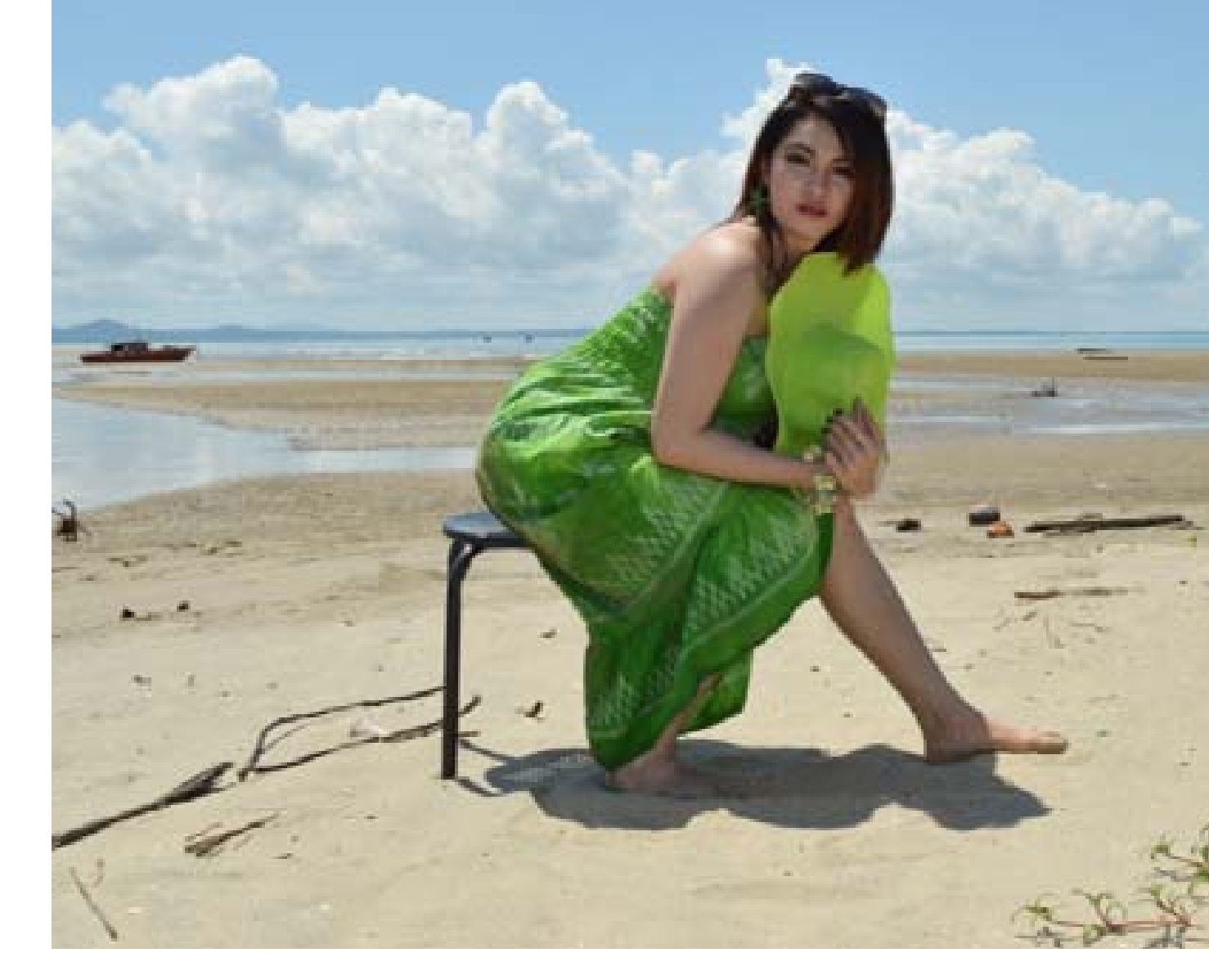

Daya pikat alam tersembunyi yang kemudian membentuk sebuah maha karya Tenun Ikat

The allure of nature is hidden then form a masterpiece Tenun Ikat.

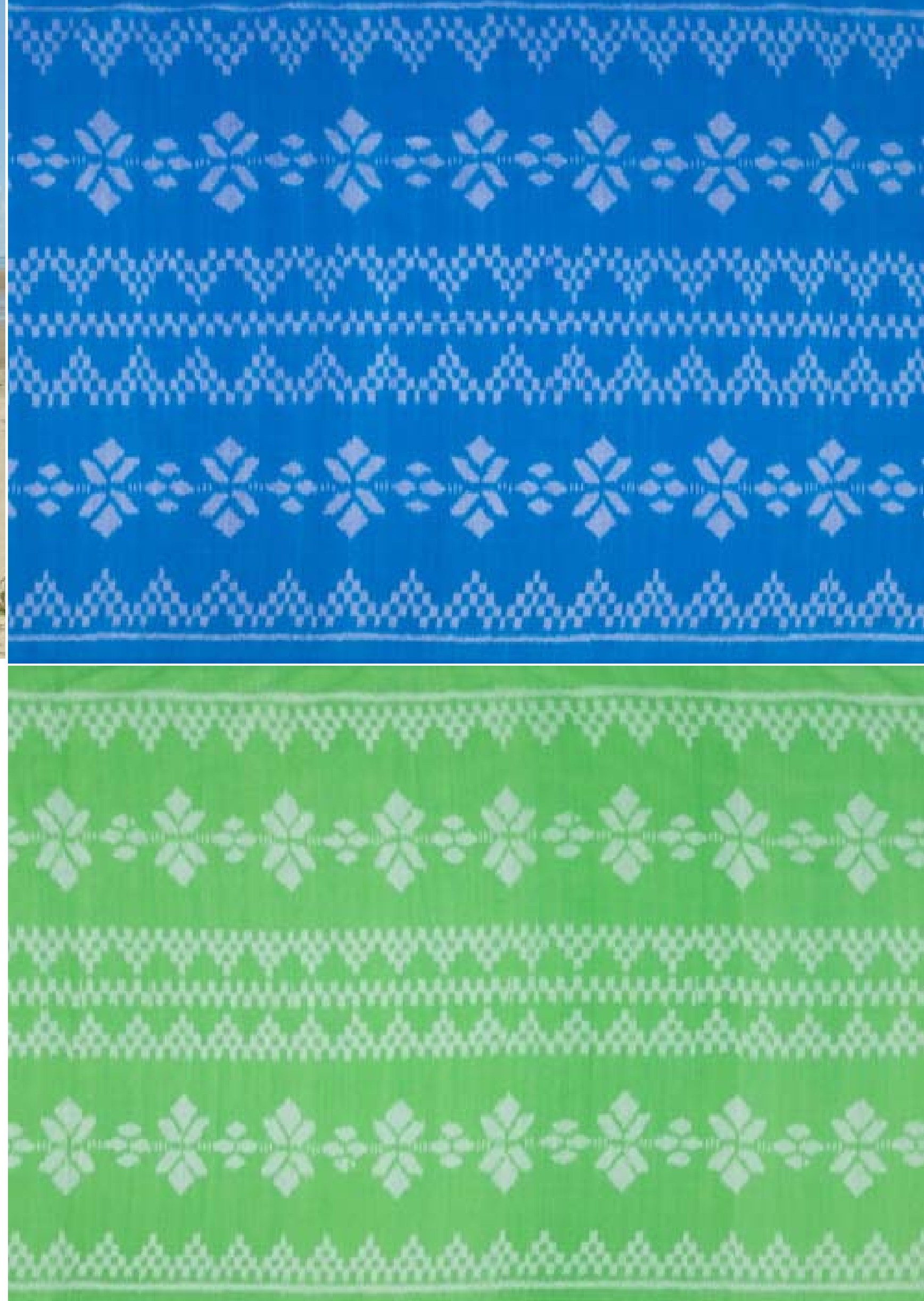





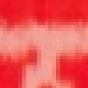

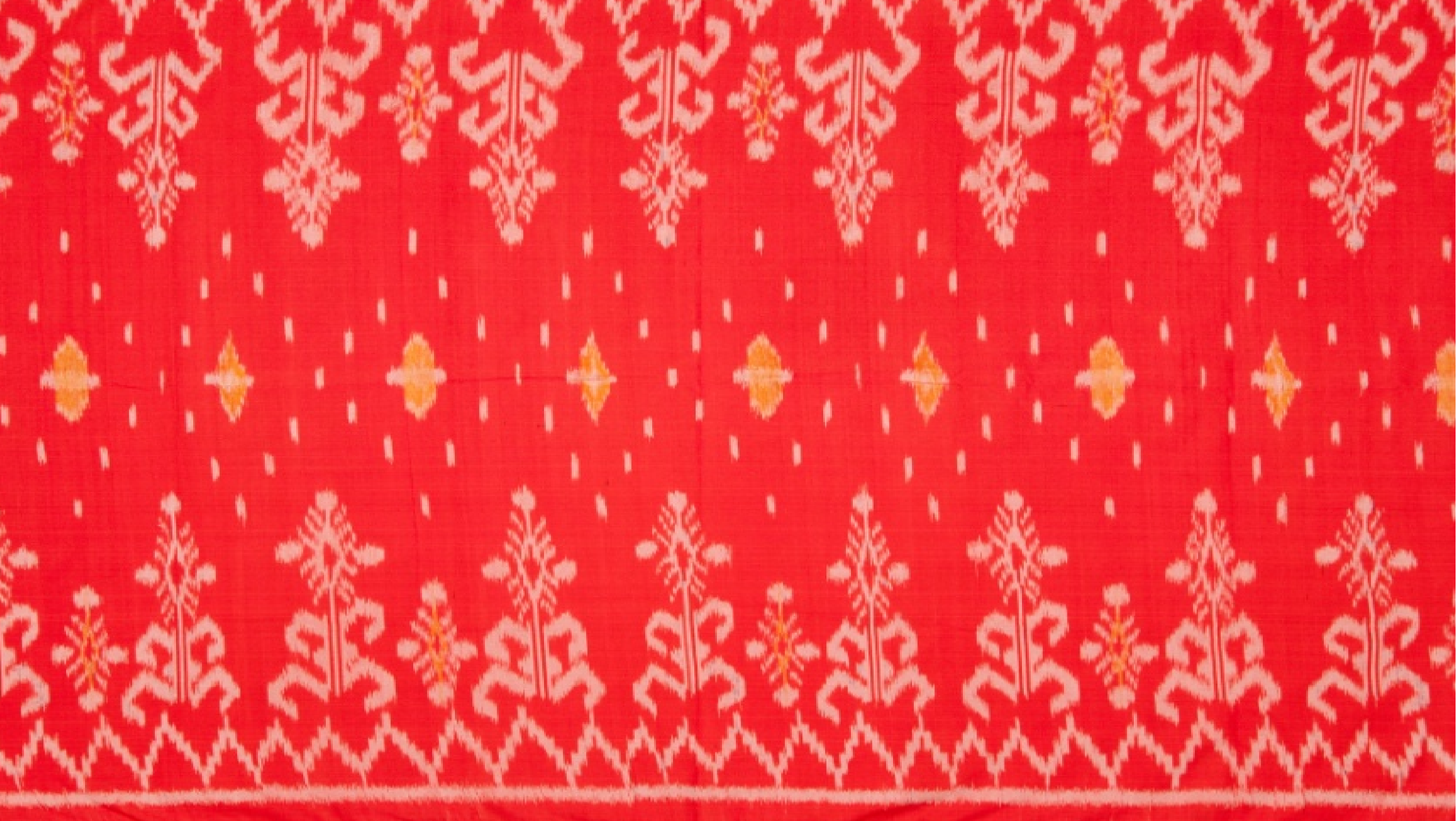

Ketajaman garis diikuti oleh warna yang berani tampil disela kokohnya untaian mutiara yang berjejer sepanjang kehidupan

Sharpness line followed by brave color interrupting the sturdy line strands of pearls along life

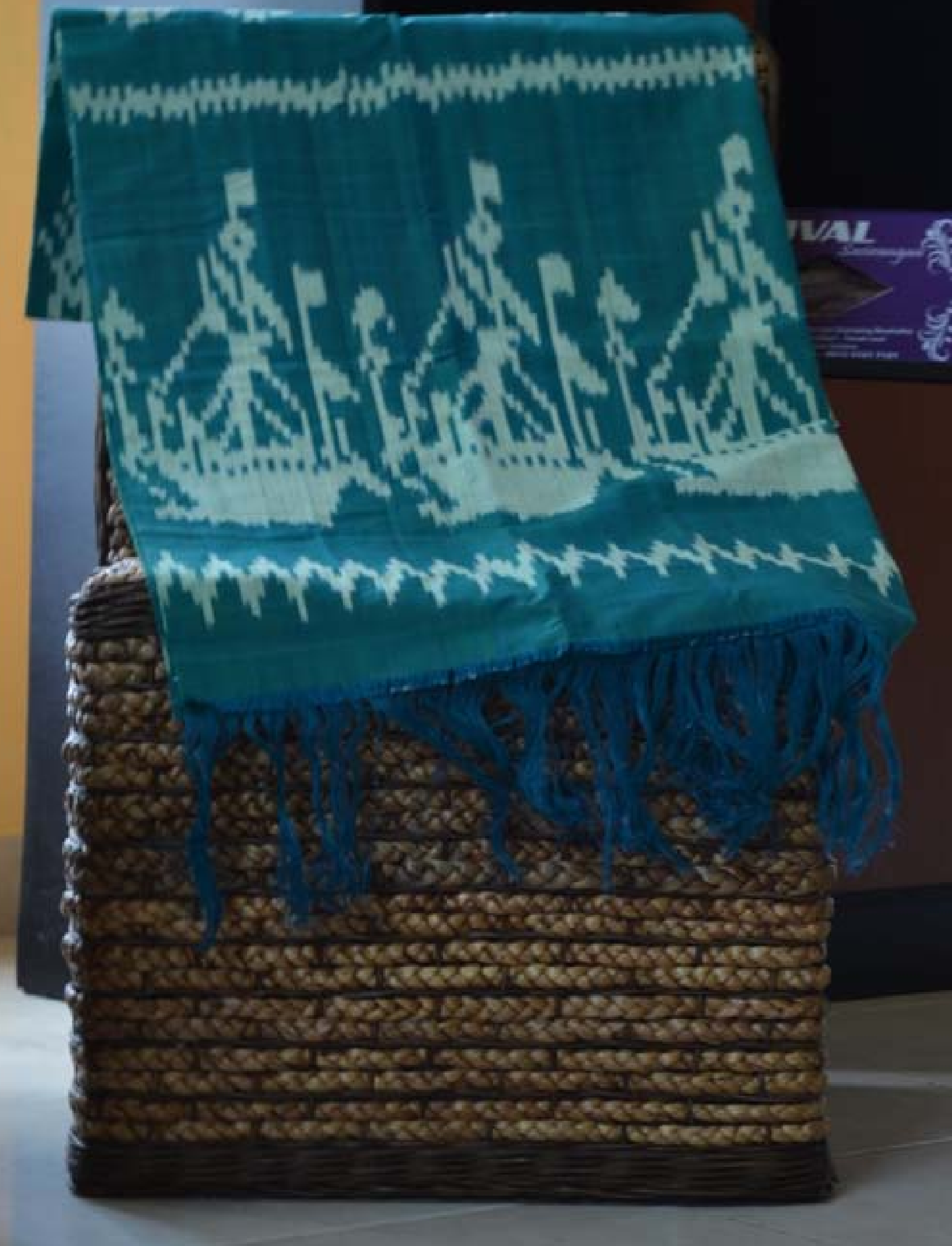

Kapal-kapal dalam cerita petualangan manusia mencari kawasan baru yang tenteram dan mensejahterakan.

Ships in adventure story of human searching for a new place, seren and prosper. 


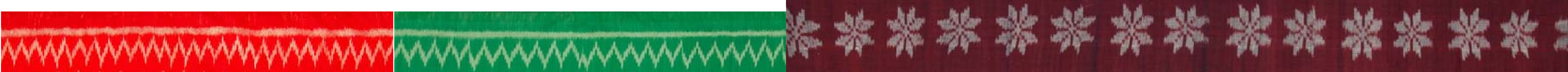

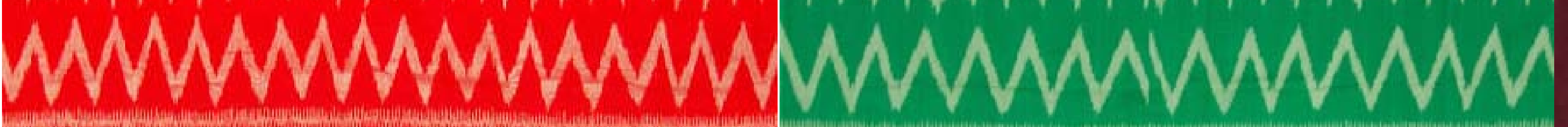

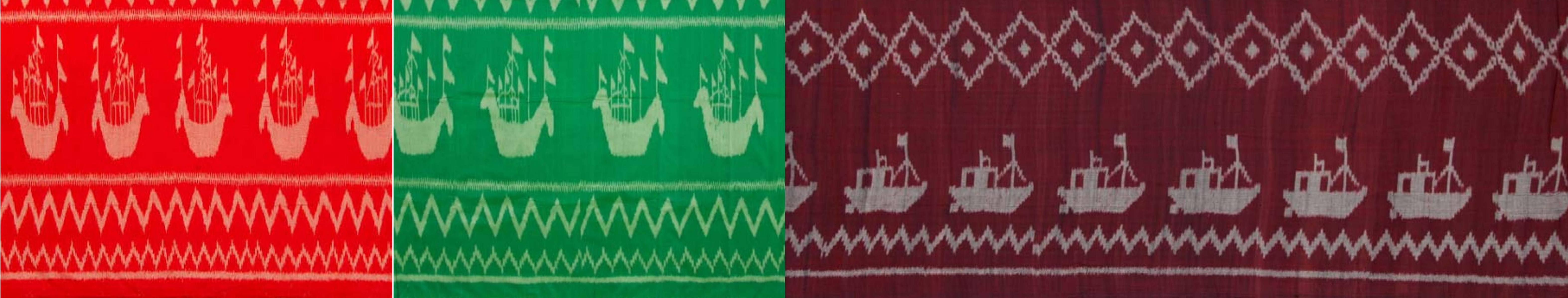




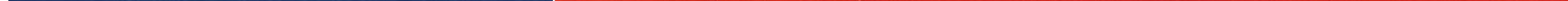





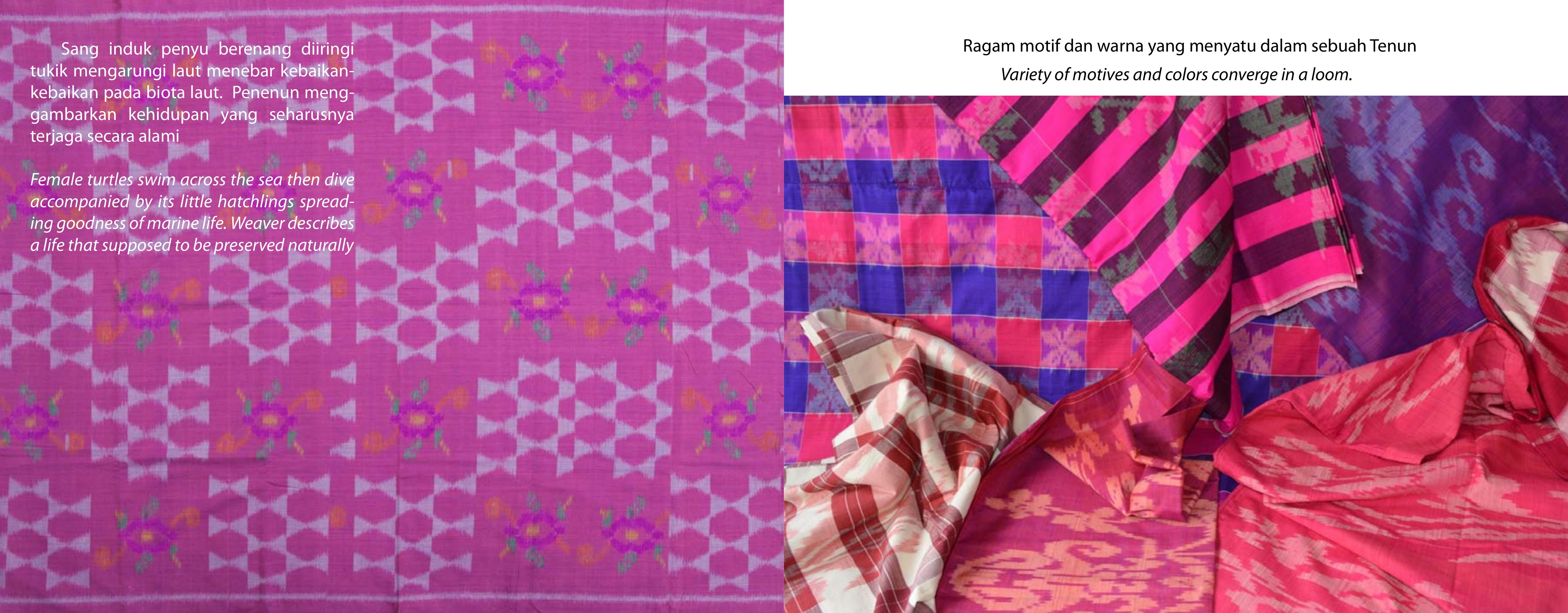




\section{Tenun Pagatan dalam Produk}

Kecanggihan persaingan pasar tekstil mesti diimbangi dengan proteksi yang kuat terhadap produk Tenun Pagatan. Diperlukan sentuhan kebijakan yang adil terhadap penenun dan kesempatan yang lebih terbuka untuk berkreasi. Jiwa kewirausahaan mereka yang sangat kuat memerlukan kepedulian semua pihak untuk terus dibangun,. Jangan sampai ini padam tersebab kita mengabaikannya
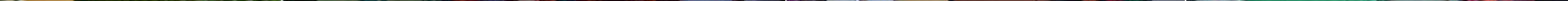


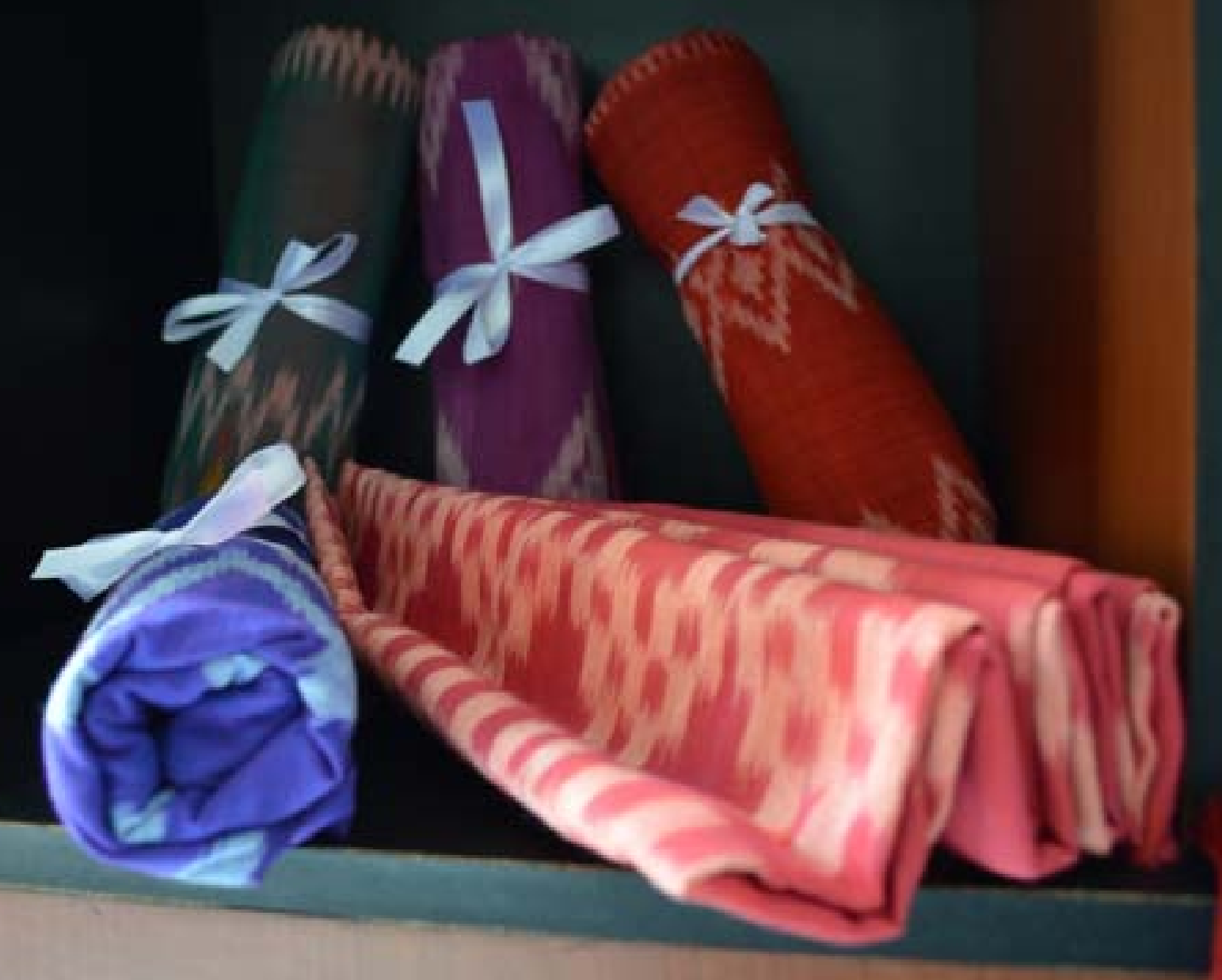




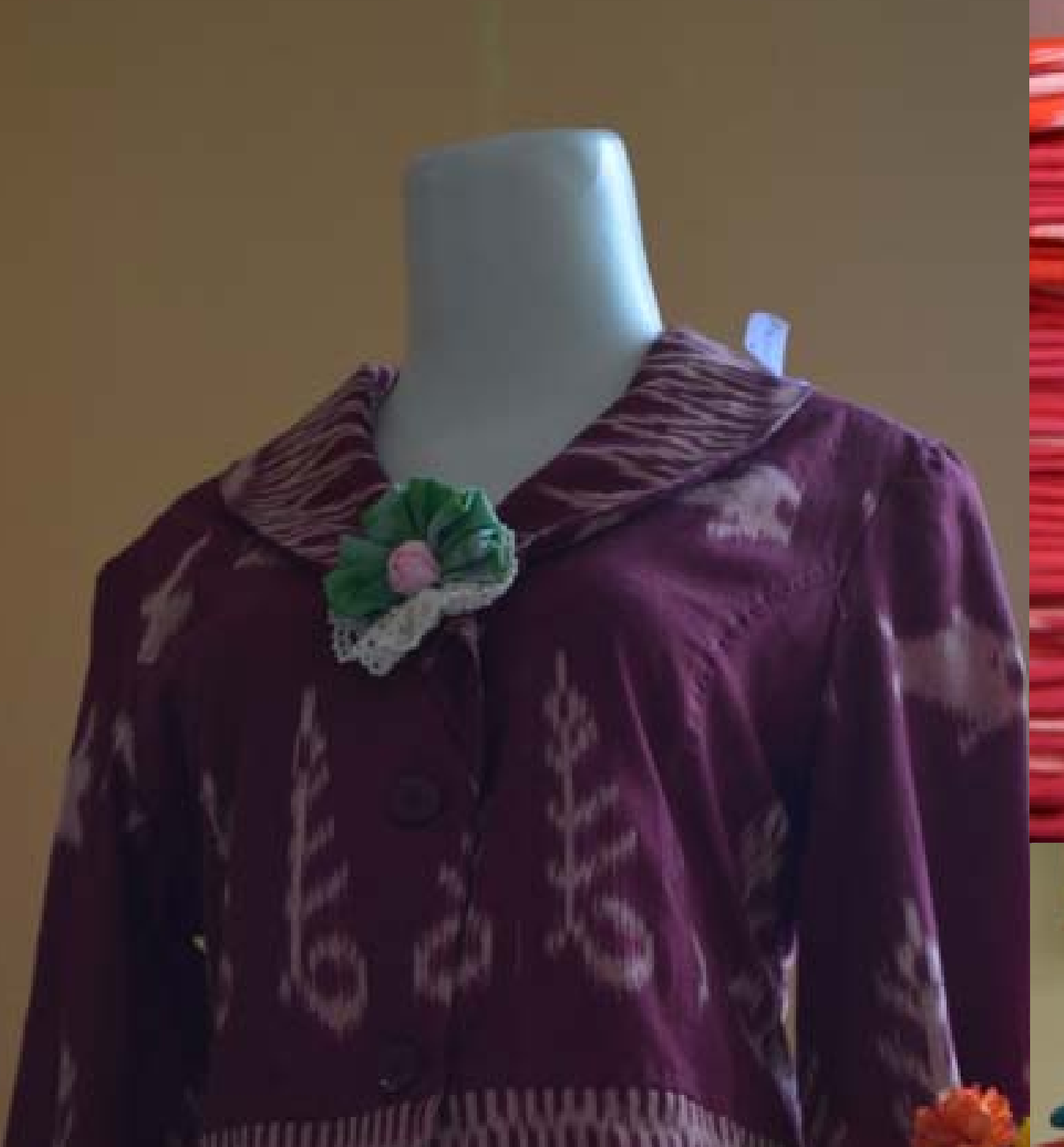

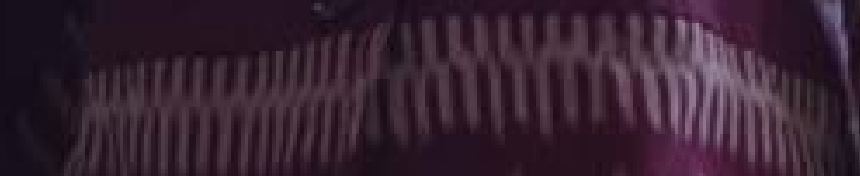

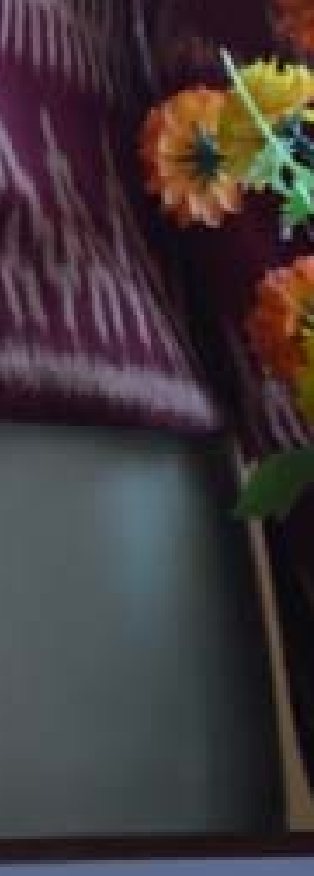

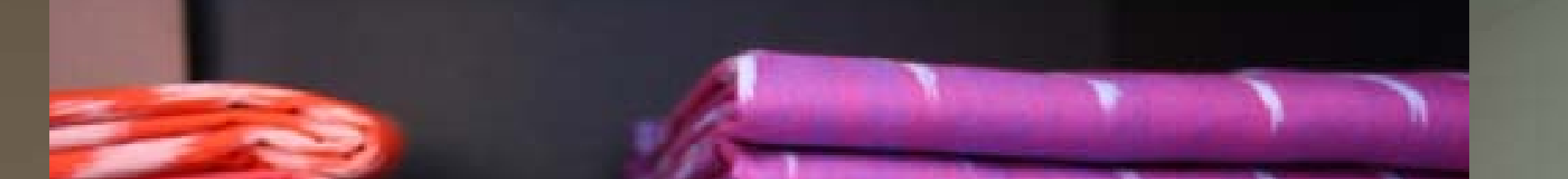

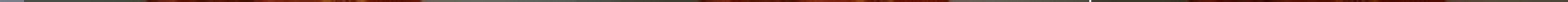




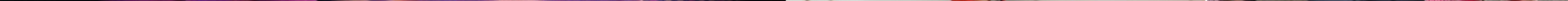




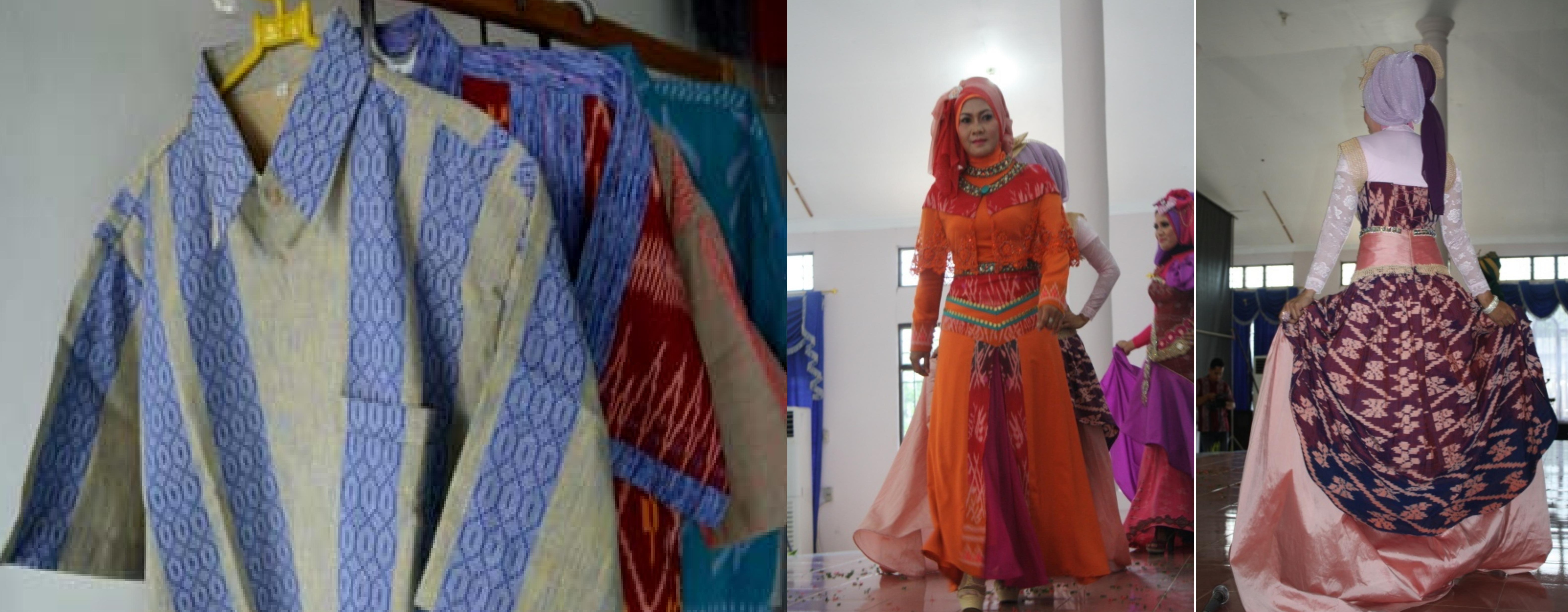




\section{Generasi Penerus}

Keberadaan Tenun Pagatan sebagai warisan budaya sangat tergantung pada cinta dan semangat generasi penerus untuk melestarikannya

\section{Next Generation}

The existence of Tenun Pagatan as cultural heritage depends greatly on love and passion of next generation to preserve it.

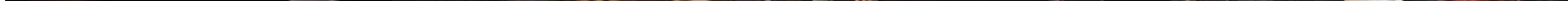




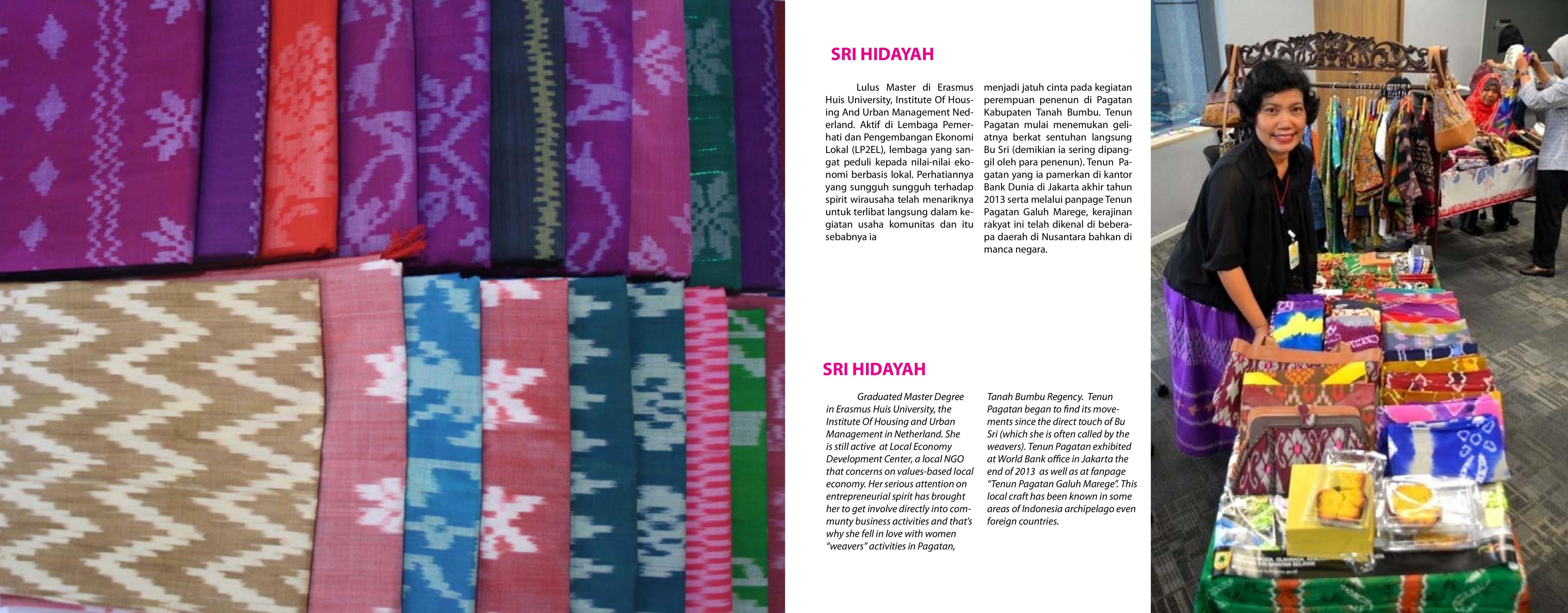


Daftar Pustaka 